\title{
Monitoring of Economic Indicators in the Context of Financial and Economic Crises
}

Dean Sinković ${ }^{1}$, Sebastian Zemla², and Nataniel Zemla ${ }^{3}$

\begin{abstract}
Financial and economic crises repeat themselves at indefinite intervals. As in the Great Recession (also known as Subprime Crisis) of 2007/2008 there was a bundle of events and processes that preceded it and contributed to its emergence, whether it be economic, political, or ideological. Based on observations presented in this paper, explanations are suggested that crises are significantly related to the development of various indicators. Relevant indicators include the impact of economic indicators (e.g., GDP, key interest rates, debt ratios), capital markets and - as the current Corona Crisis shows - supposedly unforeseen factors or shocks. The study deals with a comparative analysis of indicators regarding both crises and the Great Depression, with the aim of identifying possible trends or patterns. It uses a comparative method and reveals some significant similarities. This insight can be seen as a support for the birth of further crises. The work aims to provide a contribution to current crisis research in a comparative context and to advance findings in the field of early warning and crisis education.
\end{abstract}

KEY WORDS: $\quad$ Financial and economic crises, economic indicators monitoring and comparison.

JEL Classification: E44, E63, H69, N10, N20.

Juraj Dobrila University of Pula Department of Economics and Tourismm

Burgenland University of Applied Sciences Department of Economics'

\section{Introduction}

\subsection{Topical Introduction}

As history shows, global financial and economic crises are not isolated phenomena. They repeat themselves at indefinite intervals. Well-known crises such as the Great Depression, a global economic crisis caused, among others, by a creditfinanced speculation fever on the stock markets (Kindleberger, 1973), or the Great Recession of 2007/2008, a financial crisis caused by a real estate bubble in the US mortage market (Zeise, 2009), are two special examples that are familiar to economists in particular and sober contemporaries in general. In a crisis context there was always

Correspondence concerning this article should be addressed to: Sebastian Zemla, Juraj Dobrila University of Pula Department of Economics and Tourism Dr Mijo Mirkovic, Zagrebačka ul. 30, Pula 52100, Croatia.E-mail:sebastian.zemla@gmx.de caution and fear that such events, which have jolted the economy as a whole, may be repeated. In fact, this is exactly the kind of situation we are in right now. The current crisis, which is referred to in the media and in non-popular science sources as the Corona Crisis, is caused by a virus and has caught the entire global economy cold. The associated virus has its origin in China (Grömling, 2020) and spread rapidly to all continents in the course of global interdependencies. These dependencies have arisen in particular due to the enormous growth and global economic importance of China in recent years. In order to avoid the risk of infection, interpersonal contact was kept to a minimum. Appropriate strategies to control the transfer were also implemented, which nevertheless meant a painful experience in the context of the overall economy (Sinn, 2020a). In addition to the temporary closure of numerous production 
facilities, factories and shops, the travel industry, and the airlines in particular as well as catering and entertainment sectors were forced to face this crisis up close (Herz, 2020).

In the emergence of the current crisis and its characteristics, there are currently different evaluation and discussion patterns that shape science. Some see it primarily as a crisis caused by an "external shock" that does not really fit into the original phenomenology of the crises in the 20th century (e.g., Zürn, 2020 or Kooths, 2020). For the others, it was only a matter of time before a crisis broke out. The reasons for this can be traced back to the developments in recent years with rising private and public debt ratios as well as the formation of economic bubbles and a sluggish global economy (Sinn, 2020b or Sinković, 2020a). The observations within this paper aim to explain that economic affairs like crises are significantly related to the development of various indicators or key figure aggregates. According to reference works, relevant indicators include the impact of capital markets with regard to interest rates and equities (Brunner, 2009), economic indicators such as GDP, inflation, public and private debt ratios (Jahn, 2013) - as well as the development of stockmarkets and the real estate sector (Jahnke, 2009). The authors' choice of indicators is justified by the fact that the analysis first refers to the present economic indicators - key interest rate, inflation, and GDP - and then examines the effects on debt and stock markets. In order not to go beyond the scope of the research, a narrowing down had to be done. As a result, elementary lagging indicators such as the unemployment rate, which is also partly evident, do not come in the focus.

The present study deals with a comparative analysis of the above indicators in relation to the current Corona Crisis, the Great Recession, and the Great Depression, aiming to identify possible trends or patterns. Should such insights prove to be true they can be seen as a support for the birth and preventive handling of further crises. The work is intended to provide a contribution to current crisis research in a comparative context and to advance findings in the field of early warning and crisis education. It follows the IMRAD structure, which successively aim to answer the research question. Even if the Corona Crisis is not over, it was unavoidable for the investigation to include it due to the topicality and explosiveness of the past events.

\subsection{Research Question}

What trends or patterns in economic indicators can be observed when comparing the Great Depression, Great Recession and the newest Corona Crisis using the example of the USA?

\subsection{Literature Review}

The question about the comparability of the crises above has already been discussed in various literary works, news, and the Internet contributions. In particular, questions were discussed whether the Great Recession repeats at the same level as the one of the 1930s - with all its impacts on the financial markets, economic and political scene. The period before the Great Recession was already characterized by debauched financial markets, as Soros has pointed out. He questioned the prevailed view that markets correct themselves and saw it as a fallacy. Moreover, he spotted a selfcontradiction in the relationship between business and ethics and argued in regulation debates that "profit maximizing behavior follows the dictates of expediency and ignores the demands of morality. Financial markets are not immoral; they are amoral" (Soros, 1998). In this crisis the "concept of financial inclusiveness" examined by Nizam et al. (2020) had a special dimension after the subprime debtors with poor credit ratings there faced a wide range of loan offers and this risk ultimately resulted in crisis-relevant debt defaults. For Jahnke (2008/2009), both crises can be characterized as stages of "financial capitalism," framed by a "neoliberal globalized world." The parallels or repetitions of offenses on the capital markets as in the 1930s (including unpredictable flows of capital and money, banking crisis, collapse of the financial markets) were discussed as standard questions in various literature. The title "The Fallback - The New World Economic Crisis" translated from German in 2003 from the original edition "The End of Globalization" by James already aptly questions 
the above fact. However, the analogy found is to be classified as worrying for him.

Due to the current topic and explosiveness, an analysis of the economic consequences of the new Corona Crisis proves to be productive even at a first glance it has a completely different background. First scientifically oriented monographs such as that of Fuest (2020) are devoted to the effects of the pandemic and make initial comparisons with the Great Recession. Fuest even describes the recent crisis as "more dramatic." In addition, the work offers an insight into the voluminous stimulus packages to keep the collapse of the economy and its indicators in line as much as possible. In this regard, the view of Szysko et al. (2020) presents itself in a very contextual manner, pointing out that "once economic environment is more turbulent, the economic agents are more prone to news when (...) making economic decisisons." This includes also that central banks must make the right monetary policy decision in order to achieve a target level of elementary economic indicators - such as inflation - after the crisis.

\subsection{Methodological Approach}

As part of the methodology, the author focuses on two approaches. On the one hand, there is a qualitative analysis of existing quantitative data, in which the meaning of the quantitative results is interpreted. It involves primarily economic indicators and data that belong to the three crises. The difficulty in reanalyzing existing data is whether the data collected by other researchers fits your own question. For official statistics, it is generally advisable to use this very extensive and detailed material for your own analysis purposes in order to save the entire process of collecting primary data. It is rather a challenge not to lose sight of the vast variety and to filter out the right values that contribute to answering the question. It is not uncommon for scientists to access archived data and carry out follow-up evaluations or formulate questions (Lang, 2020).

Additionally, as further part of the secondary analysis, the author uses the methodology of comparing methods that have its origins in political science (Nohlen, 1994). The representation of the method of comparison is regarded as the "royal way of political science," because "Aristotle has already made it a central subject of his policy as an empirical-analytical science in the form of a constitutional comparison (Massing, 1974)."

As part of an explanation, it should be noted that comparisons by itself do not represent a methodical approach. Because they are also made regularly in daily life. In contrast and according to Jahn, in science the "comparative method can achieve generalizable results." On this basis, the ongoing investigation is intended to check whether a generalization can withstand several cases (or crises). The comparison is therefore not the goal, but rather the means to an end and thus the instrument. However, this methodological comparison is not carried out without reflection, but based on a logical approach. In this context Jahn concretizes additionally the actual core of this science, "to discover facts by a systematic comparison, which otherwise would be hidden" (Jahn, 2013)

Przeworski's statement also fits into the perspective above, who in comparative research prefers explanations and not comparisons as an essential component: "A consensus exists that comparative research consists not of comparing but of explaining (Przeworski, 1987)." It is also determined by scientific comparisons if established explanations prove their worth or need to be revised. For this purpose, comparison criteria must be defined in advance that go beyond the appearance of individual phenomena. The objects of investigation (the crises) should at least at first sight allow comparability, even if there are differences in character (Jahn, 2013). The extent to which the objects of investigation are comparable therefore depends on the objective of the knowledge and the comparison criteria. If comparison criteria are not properly thought out or are derived from the objective of the knowledge, the corresponding comparisons "lag" accordingly. The same applies if the criteria are not equally relevant for all cases (Abromeit \& Stoiber, 2006). In order to specifically address the subject of the investigation, it is legitimate to evaluate the connection between three crises as units of investigation and the economic 
indices or indicators such as GDP or the inflation rate (Jahn, 2013).

So, the comparative methods take effect both in economic and political sciences, only the positioning diverges. Nohlen remarked that, in social science, the comparative studies can be the method that is most relatable to political science (Nohlen, 1994). A good example is a comparison regarding different government policies, which is suitable in many ways, where policy results ("outcome") can be compared. In this regard, it is possible on the basis of comparative illustration and declaration to learn from experiences, successes, and failures of previous periods and time sections (Schmidt, 1988).

Along with systematical comparisons, the discipline of comparative politics according to Berg-Schlosser and Müller-Rommel can also use complementary other methods, such as the historical comparative methods (Berg-Schlosser \& Müller-Rommel, 2003). For example, the "comparative science of history" - according to the explanations of the historian Marc Bloch - looks "for similarities and differences in analogue rows from different social areas in order to explain them." Rather, the compared objects - in the present study the crises - will be analysed separately to compare them subsequently in certain viewpoints (Bloch, 2000).

\section{Development of economic indicators}

\subsection{Key Interest Rates}

\subsubsection{Great Recession}

Figure 1 shows a comparison of the development of key interest rates in four of the world's largest economic powers and currency zones before and after the Great Recession.

The figure shows an almost congruent picture between the eurozone, the US and Great Britain. An exception is the unvolatile base rate development of the Japanese yen. Prior to the Great Recession, the level of the latter was between 4 and almost $6 \%$ and then abruptly reduced to almost $0 \%$

\section{Figure 1}

Key Interest Rates in Four of the Largest Currency Zones

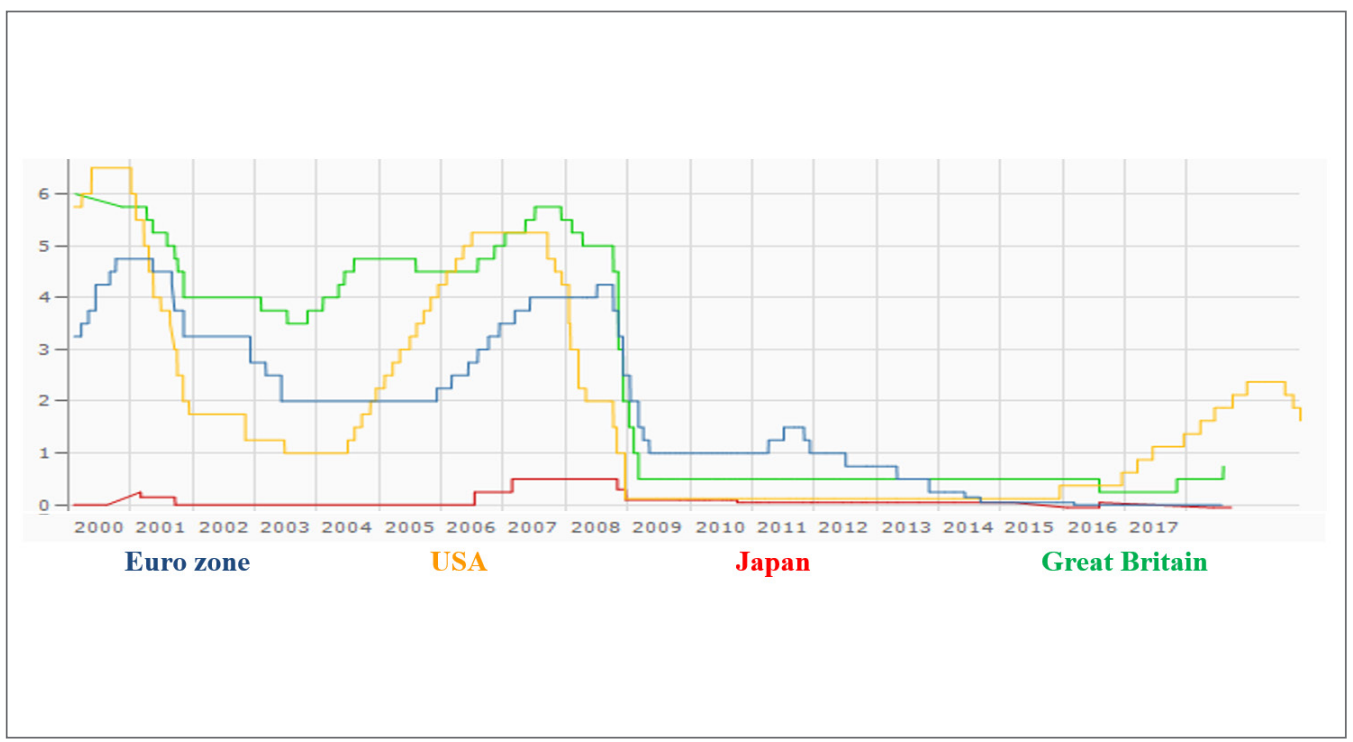

Source: finanzen.net (2019) 
when the crisis broke out. Here you can see the interest curve of the Fed was raising irresistable for three years (2016-2018) and then lowered again recently. The other currency zones quickly give the impression of a preliminary stage of the so-called "helicopter money", in which central banks first decide to keep interest rates as low as possible. If that is not enough, the direct monetary spiral will be even more exhausted (Zschäpitz, 2019). The timing

\section{Figure 2}

Effective Federal Funds Rate (in \%) of the chart also goes back to the previous recession which is associated with events of the internet- or "dotcom"-bubble and former terror attacks in the USA, which in turn resulted in quick key interest rate cuts as a monetary policy measure. After the economic situation in the USA began to recover, the key interest rate from 2004 was raised gradually by the Fed from 1\% to $5.25 \%$ in June 2006 in order to prevent an inflationary threat (Bloss et al., 2009).

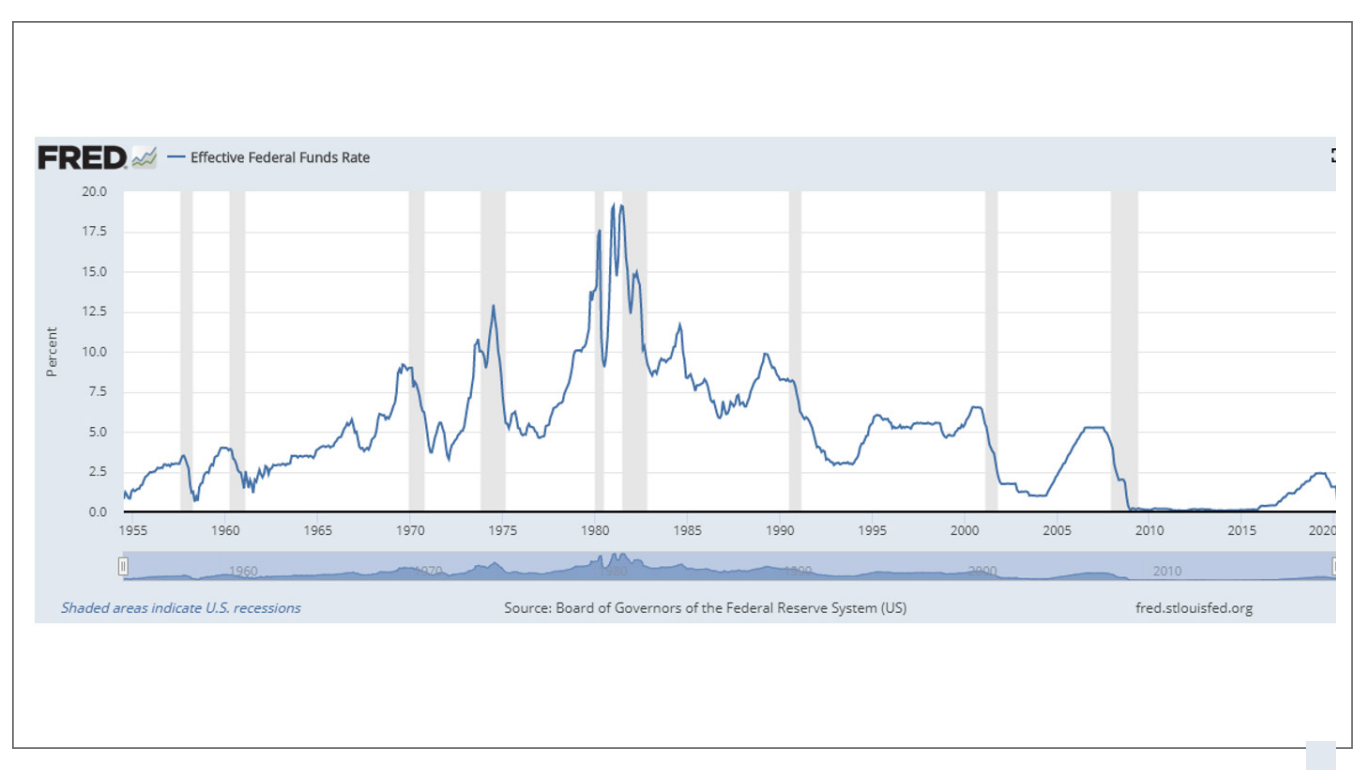

Source: Board of Governors of the Fed (2020)

Figure 2 clearly shows the development of the Fed's key interest rate in the run-up to the Great Recession and its predecessors (grey shades) with first key findings afterwards:

1. Until the outbreak of the Corona Crisis, we had been relatively free of recessions for over 12 years. It seems that an external cause like the current virus was only a matter of time.

2. The last recession (Great Recession) shows the widest - gray background - vertical.

3. Another finding is that we are currently in the longest period of low interest rates in history.

4. The highest interest rate level (1980/1981) is at first sight attributable to a short-term effect.

\subsubsection{Great Depression}

Figure 3 includes the key interest rates of the Fed before, during and after the Great Depression. The Great Depression can be found under no. 5 with the widest shaded background. The graph shows that the Fed cut key interest rates immediately when the crisis broke out, but also raised them again to almost $4 \%$ in the relatively short term. This step was not conducive to the long period of severe depression, especially since general economic activity slowed and many other countries had also entered recessions. In addition, the monetary base did not grow as monetary policy was not relaxed enough (Fricke, 2016; Davies, 2012). 


\section{Figure 3}

Recessions and Federal Funds Rate (1914-1958)

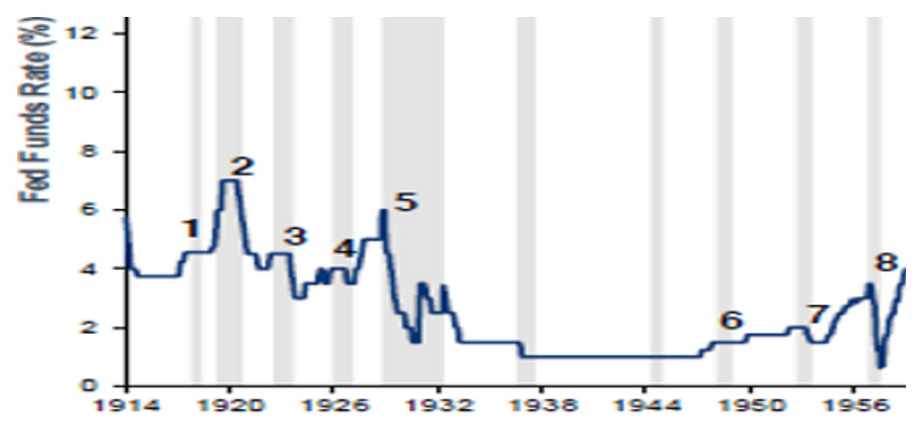

Source: Stoeferle \& Valek (2018)

\subsubsection{Corona Crisis}

Figure 4 shows the continuation of Figure 1 including the current crisis. With the exception of the United States (US), instrumental interest margin was no longer possible, since the other three currency zones were practically on the zero percent line shortly before the crisis broke out. The US due to the crisis was also forced to aim at this level again.

\section{Figure 4}

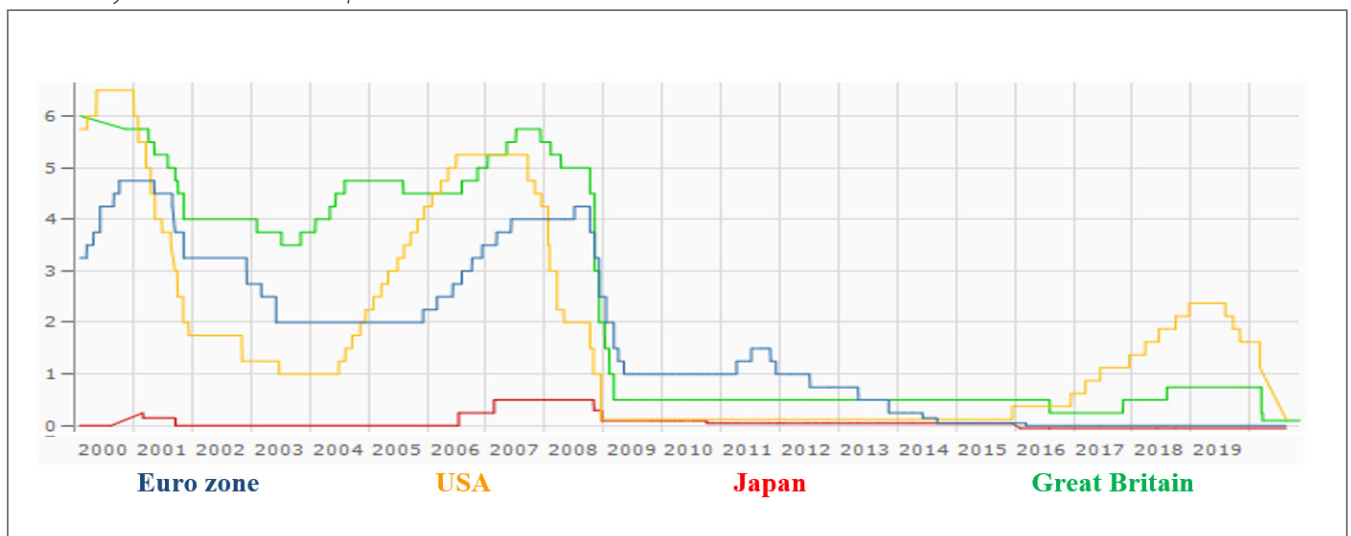

Source: finanzen.net (2020) 


\subsubsection{Comparison of the Partial Results and Preliminary} Discussion

Figure 5 shows some remarkable findings regarding the US historical key interests.

Looking back on the first remarks and history, it can be summarized that there are various reasons which can cause recessions (external shocks to the economic system such as a pandemic, debt accumulation or bubble formation and banking crises). The figure shows the respective crises in column form and first confirms that 16 of the last 19 interest rate hike cycles ended in recessions. Second, every financial crisis was preceded by rate hikes. Only three cases proved to be exceptions to the rule. These findings are not entirely negligible in the financial science context. For outsiders, this is an extraordinary gain in knowledge. For experienced market observers it is a more explainable than inexplicable connection. The last fear of such a follow-up effect was in late December 2018 or early 2019, in which the contraction of central bank balance sheets was closely related to the rising interest rates. Over the course of 2018, the Fed started to withdraw liquidity from the financial markets for the first time since the end of the Great Recession. The ECB, Bank of Japan and Bank of England were also facing this decision (Stoeferle \& Valek, 2018). After the Fed raised its key interest rate from 2.25 to $2.5 \%$ on December 19th and announced two more for 2019 plus a quantitative tighting (Federal Open Market Committee/FOMC, 2018), this decision and phase almost led to a collapse of the stock markets in the US and Europe (see Figure 16). For this reason, this consideration was largely refrained from in the course of 2019 through multiple key rate cuts (FOMC, October 30, 2019).

Another key message in Figure 5 appears to be accompanied by strengthened monetary policy instruments that have led to a monetary flooding of the capital markets. It indicates that the greatest innovations and added value were created by 1980 since then, neoliberal policies have been introduced and the financial sector has taken a leading role in the economy (Sinković, 2020b). Werner revealed an aspect that is more scientifically founded than perceived by everyone in practice. In his view, it does not correspond to today's reality that a negative correlation between interest rates and growth means that low interest rates lead to increasing economic growth. He believes that the opposite is the case. The correlation between interest rates and growth is positive what means that high growth leads to high interest rates and low growth to low interest rates (Werner, 2012). Reciprocally, this means that the elementary instrument of central banks interest rates - "cannot explain GDP growth or the behaviour of stock markets or exchange rates" and thus directly addresses Werner's critical stance on central banks. Already in 2002, he accused the central banks of "manipulating financial markets", being intent on "generating and intensifying economic cycles" and driven by pure "quantity quotas for bank credit creation of all countries". In combating the crisis, he attaches far greater importance to the factor money supply than to interest rates themselves: "What really moves the markets, however, is not the price of money, i.e. interest rates, but their quantity - if only measured correctly (Werner, 2002)." This passage shows that there are quite different perspectives in the context of central bank policy.

\section{Figure 5}

Recessions and Fed Funds Rate (1914-2018)

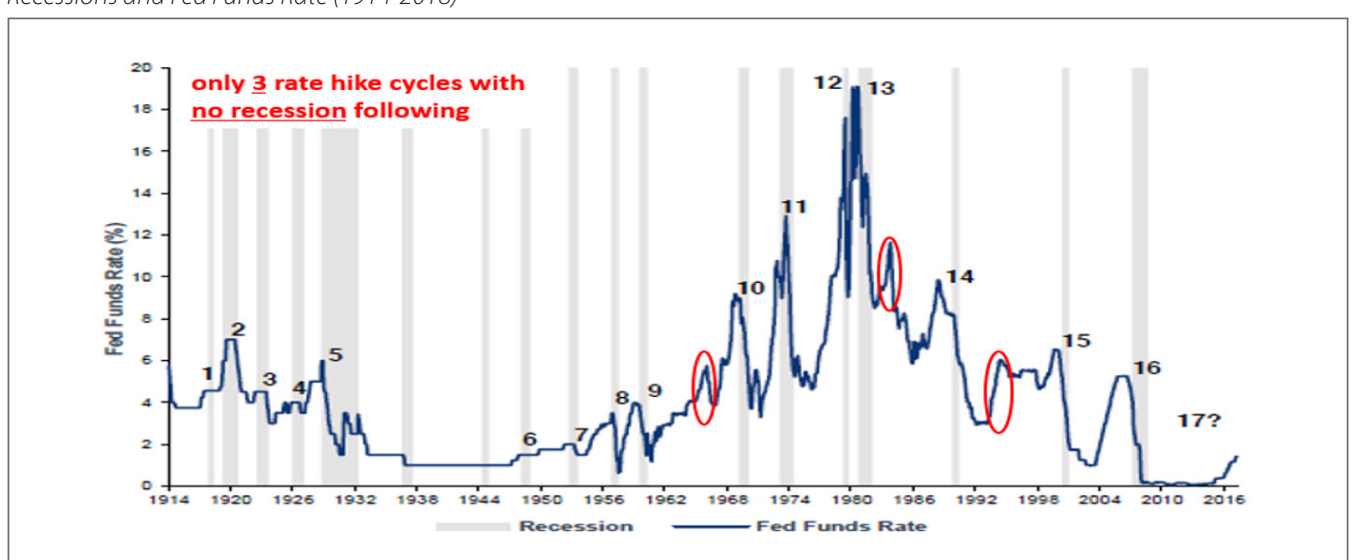

Source: Stoeferle \& Valek (2017) 


\subsection{Inflation}

\subsubsection{Great Recession}

This subsection first begins with the inflation chart concerning the Great Recession period (Figure 6).

At first sight, the graphic shows volatile effects in the context of inflation developments over the past 20 years. On closer inspection, it only moves in a corridor of rounded 0 to $4 \%$ currency devaluation or price increases. However, two periods are more striking here. Firstly, the enormous drop from 2008 to 2009 and back as well as the decline from 2014 to 2015. The highest level of inflation in this chart was shortly before the outbreak of the Great Recession, in particular caused by an extremely sharp rise in energy costs (household oil, gasoline prices) and by rising food prices (such as prices for grain and baked goods as well as fruit and vegetables). The weak dollar was also part of the increase in the consumer price index, as this means that imports of goods are based on higher prices. Inflation ended when the signs of the Great Recession began and consumers withdrew their purchases and consumer spending. A slight drop in prices also affected new vehicles, computers, and computer equipment. In this context the thesis "recession kills inflation" is appropriate, which researchers in the field of economic cycles put forward (Smith, 2008).

\section{Figure 6}

Inflation, Consumer Prices for the US (2000-2019)



Source: World Bank (2020)

\subsubsection{Great Depression}

Figure 7 shows the US inflation in a 15 -year period around the Great Depression (1923-1939).

The recessions and crises that occurred at that time are visible. Not surprisingly, the Great Depression is the thickest gray column in this graphic. The volatility of inflation shown before and after the Great Depression extends far beyond what we have experienced in the past 20 years with its dimensions from $-10 \%$ (highly deflationary) to over $5 \%$. And yet the period immediately after the First World War was one of the most volatile in the last century in terms of consumer prices and largely influenced by the direct (economic) consequences of the war. From 1922 until the end of the decade the consumer prices remained relatively stable. Inflationary drivers were increasingly food prices, which showed a higher volatility and a remarkable increase in 1925 . However, the relative stability from 1922 to 1929 did not mean that policymakers were not concerned with price changes: heated debates about prices and attempts at comprehensive regulation were formative for this period (Reed, 2014).

In 1929 the signs suddenly changed. In terms of price, these were very worrying times as the prices of many goods fell below their 1913 level. This included falling prices, which in combination with enormous declines in production followed the declining economic trend. In terms of numbers the overall consumer index fell from October 1929 to its lowest point in April 1933 by 27,4 \%, as seen in figure 7. All major consumer price categories were lower in June 1933 than in 


\section{Figure 7}

US Consumer Price Index (All Items) in Times of the Great Depression

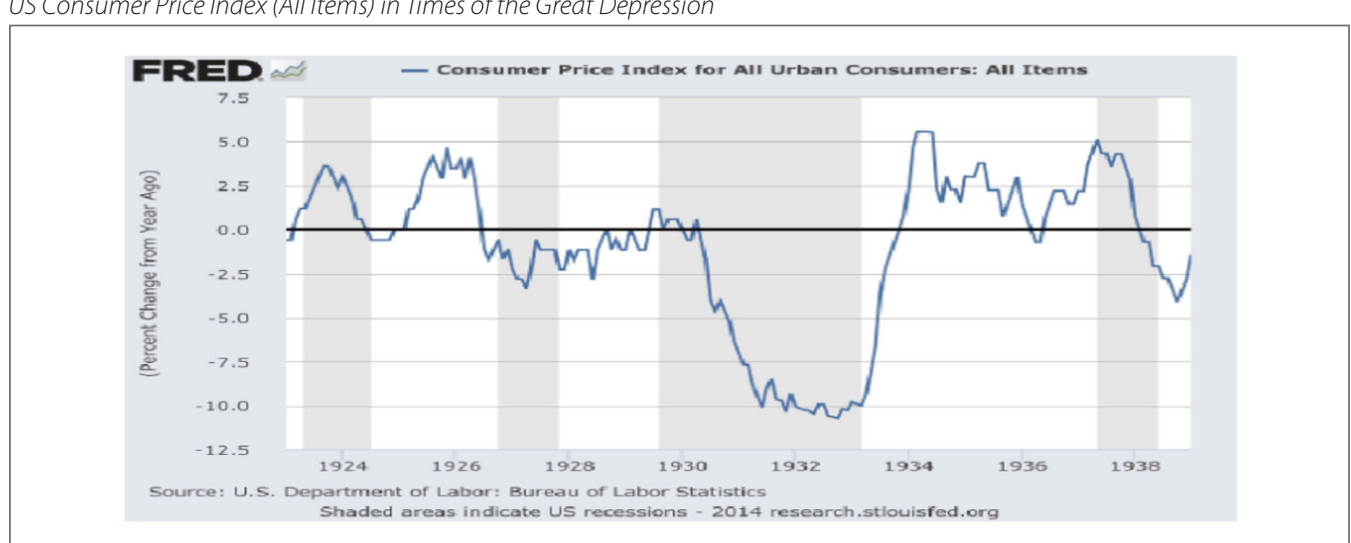

Source: U.S. Department of Labor: Bureau of Labor Statistics (2014)

June 1929. The most volatile commodity prices were still food and clothing which accounted for almost $30 \%$ of a household's expenses. At that time groceries in particular took over a more dominant part of the market basket, compared to today. And this proportionality was even higher at the time of the world wars (Reed, 2014).

\subsubsection{Corona Crisis}

The following overview includes the current inflation level as of October 2020 (Figure 8):

Similar price developments like the IMF forecast in the graphic (1.5\%), the U.S. Bureau of Labor Statistics announced on December 10, 2020, an increase in consumer prices in the USA of 1.2 percentage points compared to the previous year. That means, inflation is still on the rise because it was just $0.3 \%$ for April and suffered then the biggest drop since December 2008 (Great Recession). While total energy prices as of April were still $-17.7 \%$ compared to the previous year's level, this price decline was reduced to $-9.4 \%$ as of November. This development is mainly due to a slump in crude oil prices and due to the restrictions in air traffic. On the other hand, food prices rose significantly (as of April $3.5 \%$ and as of November 3.7\%) which can be seen as a direct effect of the crisis (U.S. Bureau of Labor Statistics, 2020a/b).

\section{Figure 8}

Inflation Rate, Average Consumer Prices of US and EU Majority



Source: IMF (Annual percent change), October Outlook 2020 


\subsubsection{Comparison of the Partial Results and Preliminary Discussion}

Figure 9 shows, in a 60-year view, with red circles that inflationary and deflationary movements follow a certain pattern before and after the outbreak of crises, including four economic recessions and two energy crises (Bryan, 2013). The graphics combined with the elaborations in this section have truly shown that striking price increases often accompany crises (e.g., price speculation as in the Great Depression or Great Recession) and that the inflation rate is largely high before the outbreak of a crisis. Conversely, deflationary developments are compatible with the immediate consequences of the crisis. The latter can also be observed essentially in the wake of the Corona Crisis.

\section{Figure 9}

Inflation, Consumer Prices for the US with Own Circles

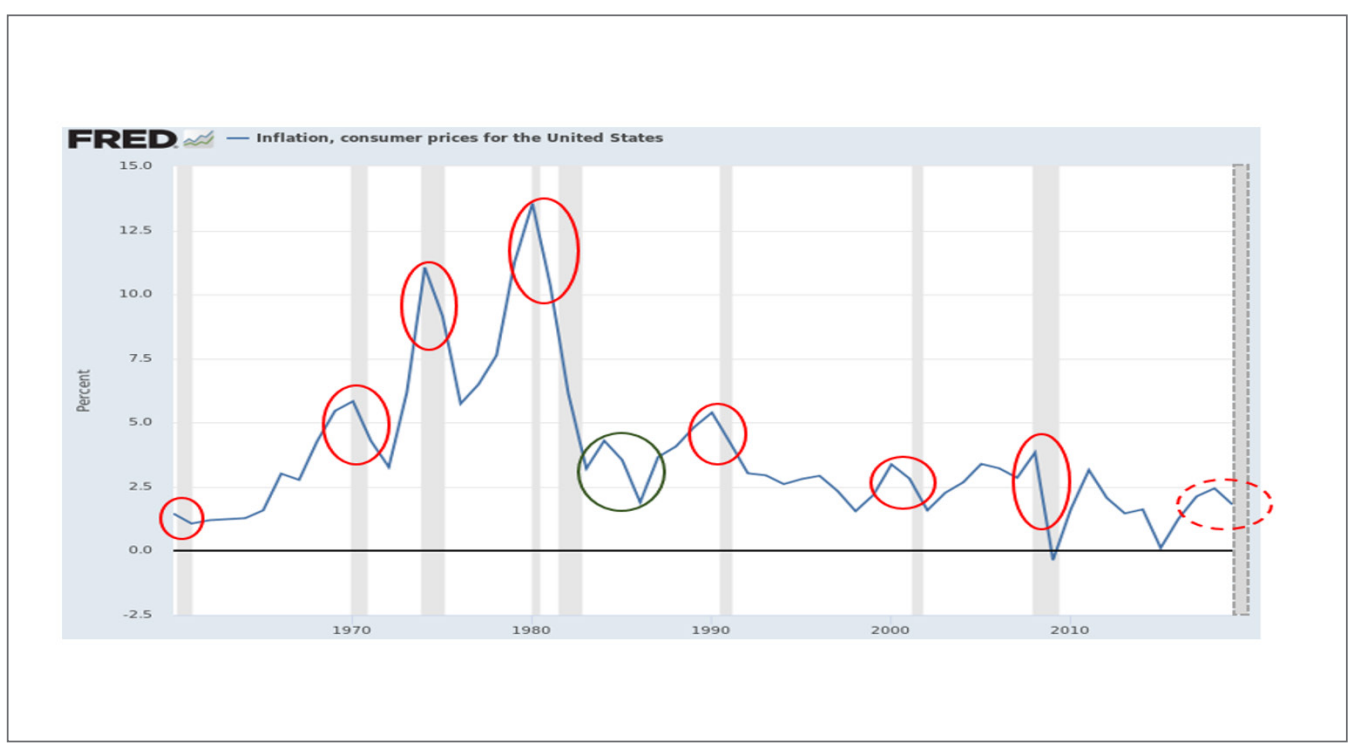

Source: World Bank (2020)

The most advanced deflationary developments can be observed in the 30s (figure 7), this was also responded to with clear criticism of the fiscal policy measures. With regard to the classic history of American monetary policy, well-known economists such as Friedman or Jacobson Schwartz (Friedman \& Jacobson Schwartz, 1963) blamed the Fed for not having contained a large part of the crisis by failing to prevent the decline in the money supply after 1929. Such moves would have resulted in more intense free market government bond purchases, where banks and other companies would have had sufficient liquidity to meet their growing demand for cash (Davies, 2012). Another alternative "to inflate the economy" would be through a change of government combined with a new economic program, as was done in the spring of 1933 by President Roosevelt with the New Deal (Daniel \& ter Steege, 2020)." That means that inflation can be controlled through fiscal measures. Deflation often leads to an increase in credit defaults and bankruptcies, which in turn goes hand in hand with a number of bank defaults and results in a further decline in income, production and employment. The Fed generally push price stability as a primary objective of monetary policy, as fluctuations in price levels can lead to financial instability and can slow economic growth (Wheelock, 2007). 


\subsection{GDP Development}

\subsubsection{Great Recession}

Figure 10 is the historical representation of the GDP course with the special outlier in 2009:

The chart reveals the impressive finding that gross domestic product fell significantly more from 2008 to 2009 than in the previous ten recessions after the Second World War. It can be seen that GDP has been rising steadily since 1970, with the exception of the sharp slump in 2009, which outlines a very short phase and then rises steadily and unstoppably.

\section{Figure 10}

US GDP 1947-2015 (\$ billion)



Source: U.S. Bureau of Economic Analysis (2020)

\subsubsection{Great Depression}

The following considers the GDP development during the Great Depression (Figure 11).

Real GDP fell by a significant 25\% between 1929 and 1933, which already indicates in numbers that the extent of the decline in was considerably more burdensome than during the Great Recession. Davies cites various factors that contributed to this development. For one thing, the economic conditions in early 1932 were worse than ever in the
US history. Both real GDP and industrial production had not only stabilized, but were on the way to a decline from the 1929 peak of 27\% (GDP) and 52\% (industrial production). To make matters worse, deflation raged at an annual rate of $-10 \%$ in 1932 , which increased the real burden of outstanding debts at an alarming rate and also had a negative impact on GDP. In addition, there were two major bank failures before 1932, limiting the money supply by $33 \%$ from its 1929 high (Davies, 2012).

\section{Figure 11}

Real GDP/Industrial Production Index 1929-1941



Source: Federal Reserve Bank of St. Louis (2012) 


\subsubsection{Corona Crisis}

This subsection is devoted to the development of GDP as a continuation of Figure 10, including the influenced GDP by the corona epidemic.

It becomes clear what economic researchers appreciated early on: the (global) economy is suffering massively from the effects of the Corona Crisis which is reflected in particular in the following figures: as early as the 1st quarter of 2020, in which the pandemic only brought restrictions from March onwards, the US economy (GDP) already declined by $-4.8 \%$ (U.S. Bureau of Economic Analysis, 2020). In the meantime, costly and extraordinary economic stimulus programs will be essential, also through massive bond purchases including aid packages at the peak of up to $\$ 2$ trillion (Powell/ CBS News, 2020).

Figure 12

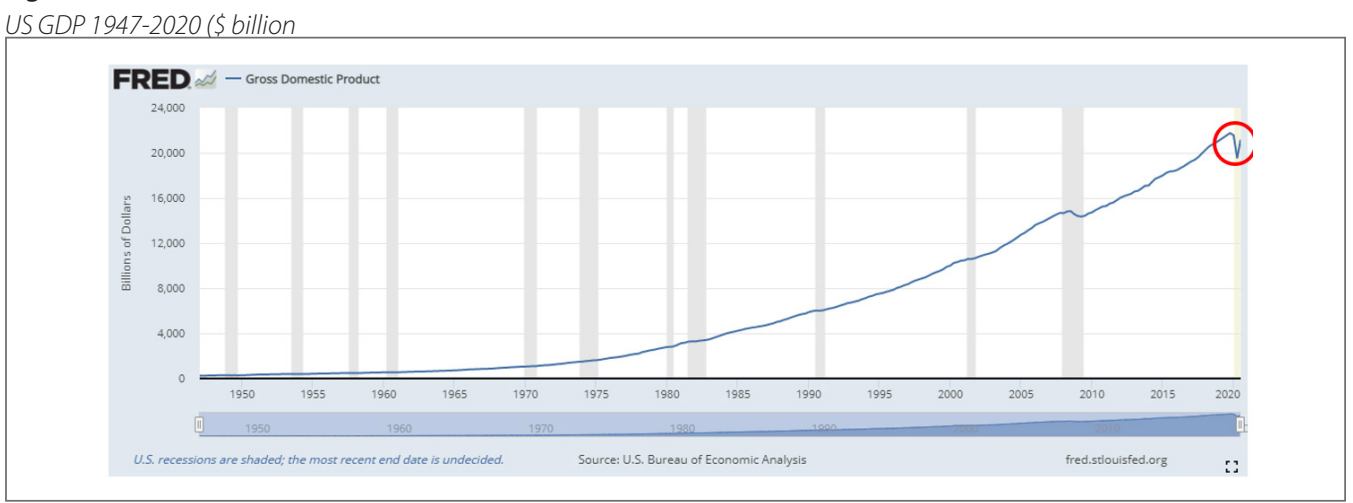

Source: U.S. Bureau of Economic Analysis (2020)

\subsubsection{Comparison of the Partial Results and Preliminary Discussion}

For the comparative analysis of this section and as already elaborated in the previous two sections it turns out relatively quickly that for the 1930s characteristic elements of a restrictive monetary policy are evident. Fricke's overall impression of the 1930s is unambiguously condensed into the following critical dogma that the economy was insufficiently supplied with money and credit with negative effects for production and consumption: "Back then, governments and central bankers had watched for a long time, bankrupted banks and relied on letting the supposedly purifying crisis run until it became independent and ended in deflation and depression. Back then, the monetary authorities kept interest rates relatively high for years and the money supply shrank. As a result, companies and households had a quarter less funds available in 1933 than in 1929." This explains the reason why the then Fed chief Ben Bernanke after years of research into the Great Depression took a different route after the crash in 2008 (Fricke, 2016). Based on his remarks expansionary monetary policy in a battered phase "can help calm the market, can help stabilize those institutions, and can help mitigate or end a financial crisis" (Bernanke, 2013). He quickly put a lot of money into circulation and lowered interest rates to zero to prevent the money supply from falling. It also explains why Obama's advisers opted for similar interventions, including restructuring state aid banks, increasing spending and bringing money to the people. Even if it dramatically increased government deficits (Fricke, 2016). In the context of GDP and its effects the thematic focus of the economists Jordà, Schularick and Taylor is that the "correlation of production, consumption and investment growth with credit has increased significantly over time." In their view, loans even more than money are now more closely associated with GDP changes than in earlier, less indebted periods of 
modern economic development. According to them the same thesis also applies to the correlation with investments and consumption (Jordà et al., 2016), becomes obvious that offering loans in times of crises through government programs and with the support of the central bank to cut interest rates has a positive effect on GDP.

Based on first expansions of the money supply (purchase of government bonds and detachment from the gold standard in 1933) it was possible that the US economy was able to reach the pre-crisis level after 1937 as seen in Figure 11 (Davies, 2012). Here, the numbers of economic performance after the outbreak of the Great Recession speak a divergent language. The downturn in the US economy after the crash in 2008 lasted just one year, followed by three years of the economic crisis instead of almost a decade of depression after 1929. If you compare the unemployment rate in the wake of the Great Depression (25\%) it becomes clear that the resulting slowdown in consumption also contributed to the economic collapse and companies were also forced to reduce their investments. At the time of the Great Recession the US remained far from comparable mass unemployment. And eight years after the outbreak of the crisis the official unemployment rate was even below 5\%. In addition, per capita consumption in 2011 was again at the pre-crisis level. As a result of all this development and including recurring economic growth, it was also possible from 2010 to generate tax income that is necessary to reorganize the state budget due to the costly economic programs (Fricke, 2016). It is therefore not surprising that in the current crisis extensive stimulus packages to contain the effects of the crisis have been adopted. Among other things, this is the Coronavirus Aid, Relief and Economic Security Act (CARES) worth \$ 2 trillion which includes quick and direct economic support for American workers, families, and small businesses, particularly designed to help maintain jobs for American industry (U.S. Department of the Treasury, 2020c).

\subsection{Public Debt Developments}

\subsubsection{Great Recession}

This subsection deals with a long historical development of public debt ratios, the development of which is to be examined in the context of the crisis (Figure 13).

\section{Figure 13}

Federal Debt: Total Public Debt as Percent of GDP




What stands out immediately is the extreme debt surge since the Great Recession. In no other crisis shown in the graph such an increase can be seen historically. The huge rise in debt ratios is an immediate consequence of a particularly serious slump in the global economy after the Great Recession. Since the reduction of the debt surplus of households and companies goes hand in hand with a persistent dampening of growth, the debt ratio of the government rose in the course of this financial crisis. It must be noted in line with Illing that the sharpest worldwide rise in government debt ratios since the Second World War is a reflection of the high costs of the financial crisis and the stimulus packages (Illing, 2014).

\subsubsection{Great Depression}

Looking at the period of the past 100 years in U.S. history
(Figure 14) it is striking that the debt level within the Great Depression period is not comparable to that of the post-war period of World War II and its special circumstances, even if a marked rise with the onset of the crisis phase is visible.

And, with regard to the public debt ratio, there is a significant difference which gives a special attribute to the respective crisis. The magnitude of just over $40 \%$ of GDP shows the apparently divergent political trend at the time of the Great Depression towards savings-oriented monetary policy while the Great Recession and its history can confidently be credited with a special role in relation to private and public (here: $>80 \%$ ) debt ratios. The double amount of the aforementioned rate illustrates the origin, already described in the course of the investigation, of not having been reluctant to incur more debt due to low interest rates (e.g., Münchau, 2008).

\section{Figure 14}

Federal Debt Held by the Public (Last 100 Years View in \% of GDP)

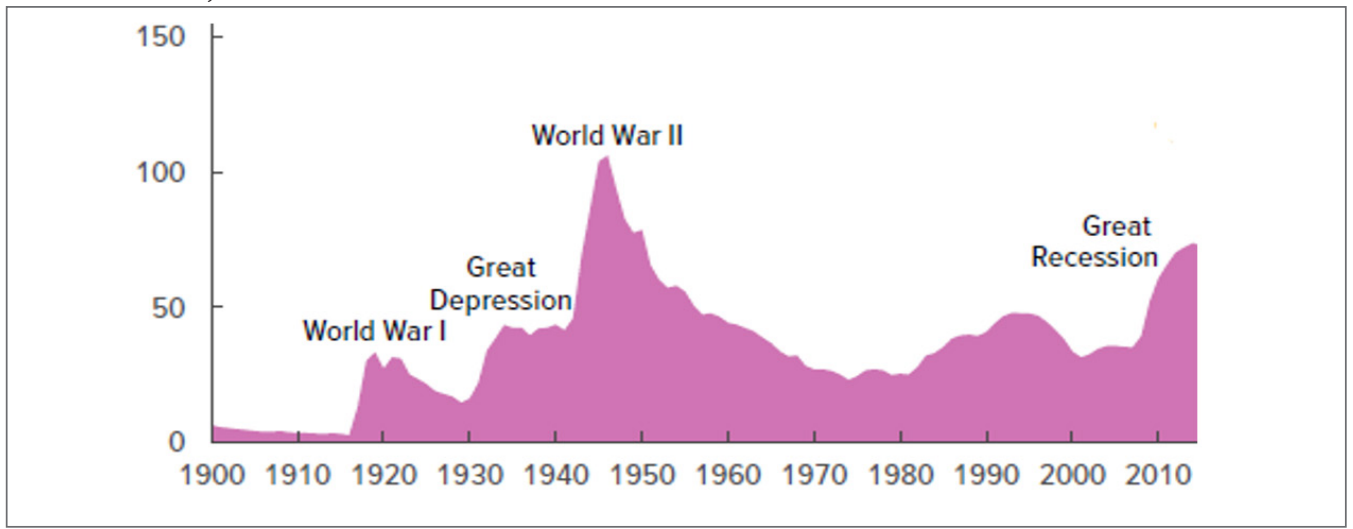

Source: Congressional Budget Office of the United States (2020)

\subsubsection{Corona Crisis}

The Treasury of the US government expresses the most elementary finding in bare figures. Since March 31, 2020, the end of the month in which the pandemic broke out worldwide, the US government's debt has soared from $\$ 23,687$ billion in less than $2 \frac{1}{2}$ months to an incredible $\$ 26,063$ billion (June 11, 2020). This shows an increase of over $10 \%$ (U.S. Department of the Treasury, 2020a/b). The government stimulus measures and the economic impact of the Covid-19 pandemic are therefore taking their toll and are largely responsible for ensuring that the debt has reached the level outlined (Jones, 2020). First calculations by US organizations dealing with this paint a dramatic picture which is not only emerging, but has become reality (Figure 15). The graphic proves that the US government debt as of June 2020 reached $120 \%$ of the annual economic output and broke the 1946 record for the highest debt in the history of the US, in times of the Second World War. The current level is four times the average in the country's history (Agresti, 2020). It is difficult to filter out positive aspects. One aspect is the 


\section{Figure 15}

Continuation of Figure 14

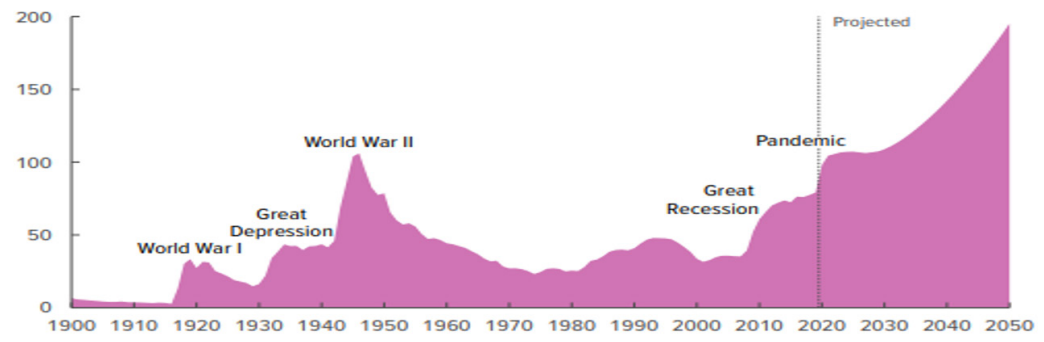

Source: Congressional Budget Office of the United States (2020)

fact that this money has the intention of being used for a good purpose, namely to support those affected by the crisis and to boost the economy. And secondly, that the current interest rate environment is making debt (very) cheap (Naumer, 2020). The graphic also shows that the debt trend resulting from the Great Recession is diametrically opposed to the situation in the Great Depression. Contrary monetary policy directions (money restriction versus money expansion) meet here strikingly based on the knowledge gained so far from the investigation (Congressional Budget Office of the United States, 2020).

\subsubsection{Comparison of the Partial Results and} Preliminary Discussion

The complex processing of the debt section has produced various insights, some of which have also been used for an antithetical discussion. Starting with the argumentation example of Sinn, two crucial points come to light. On the one hand, his endorsement of costly economic stimulus measures by the state in times of crisis which are based on John Maynard Keynes' economic policy in order to save primarily affected companies and jobs and thus support the economic cycle. On the other hand, there is the requirement of debt discipline, which is counteracted by central bank policy and meanwhile is turning away from the character of sustainability due to long-term and increasing debt paths and a tripling of the central bank money supply (Sinn, 2020b). Finding the right consensus here is like a scientific sparring match. In order to classify long-term debt constellations you must bear in mind that Reinhart and Rogoff already classified them as essential indicators in the context of crises. The results of their investigations show that de facto persistent payment difficulties and overindebtedness of states qualify as multiple crisis generators of the past centuries (Reinhart \& Rogoff, 2009). It is therefore all the more important to consider the circumstances to which governments are directly or indirectly exposed.

It is evident that in temporal context traditional monetary policy has reached its limits as a stabilization instrument in the former Great Recession and that active fiscal policy had to be used more to prevent a fatal downward spiral. It was one of the main points why a massive slump like the Great Depression of the 1930s could be prevented in many emerging countries and in most industrialized countries, including all advantages and disadvantages (Illing, 2014).

Krugman took a constructive stance on the high levels of global debt and especially in the USA even before the outbreak of the corona pandemic in a strong argumentative manner. In his eyes austerity efforts must be seen as a negative scenario if they prevent future investments in narticular in new infrastructure. Even though he views the US debt situation with relatively little panic, he sees the origin of the debt mountain as anything but uncritical. Tax relief for large corporations and tax cuts for the rich 
are two things that re not permitted in the context of debt accumulation. His historical consensus is that government debt may well increase but for a sustainable purpose, such as investment in education or infrastructure (Krugman, 2019). Otherwise, worstcase scenarios could develop that would be compatible with the austerity policy and the situation as in the 1930s and could slow down the economy (Krugman, 2012).

\subsection{Stock Markets Development}

\subsubsection{Great Recession}

This subsection considers the S\&P 500, one of the most watched stock indices in the world (Figure 16). The curve begins in a phase of rising share prices favored by the dotcom bubble at the time which flattens off again after 2000. Then began the prehistory of the Great Recession. Under the conditions of a globally operating banking industry risks from the subprime lending business had an impact worldwide, not only on the real estate markets but increasingly on the stock markets (Kremer, 2017). After that period the rising trend to the Great Recession in early 2008 followed by another with only a few or very short drops until 2018. The first collapse can be observed in December 2018 as reported before, after the Fed raised its key interest rate and announced two more in 2019 and quantitative tightening. The index rose again in line with the Fed's monetary policy decisions after the Fed cut rates three times in a row to boost the slowing economy. As of 2019, it was between 1.5 and $1.75 \%$ (FOMC, October 30, 2019). In addition to the key interest rate strategy, the visible rise in the major indices is due to renewed monetary expansion (Board of Governors of the Federal Reserve System, December 08, 2019).

\section{Figure 16}



Source: finanzen.net (2020) 


\subsubsection{Great Depression}

A historical review of the 1930s, however, allows a look at the Dow Jones stock index at that time which in contrast to the S\&P 500 already existed back then (Figure 17). A big difference between the course in this graphic and the course from the Great Recession is becoming clearer than ever.

While it took about five years after the Great Recession to reach a comparable pre-crisis level of the S\&P 500, the precrisis level after the Great Depression was far from being reached even after 10 years. The positive consequences of the so-called Golden Twenties are graphically reflected. Thanks to new branches of the economy and revolutionary inventions such as radio, sound film and assembly line production the economy at that time was experiencing a real boom with new companies regularly entering the market and later going public. Due to the industrialization after the First World War stock exchange trading increased by leaps and bounds. A final crash and further bursting of the bubble finally became a reality than in October 1929 when the Black Thursday shook the New York Stock Exchange (Seidl \& Brandt, 2018).

\section{Figure 17}

Dow-Jones Industrial Stock Price Index for United States Development 10 Years before and after the Great Depression

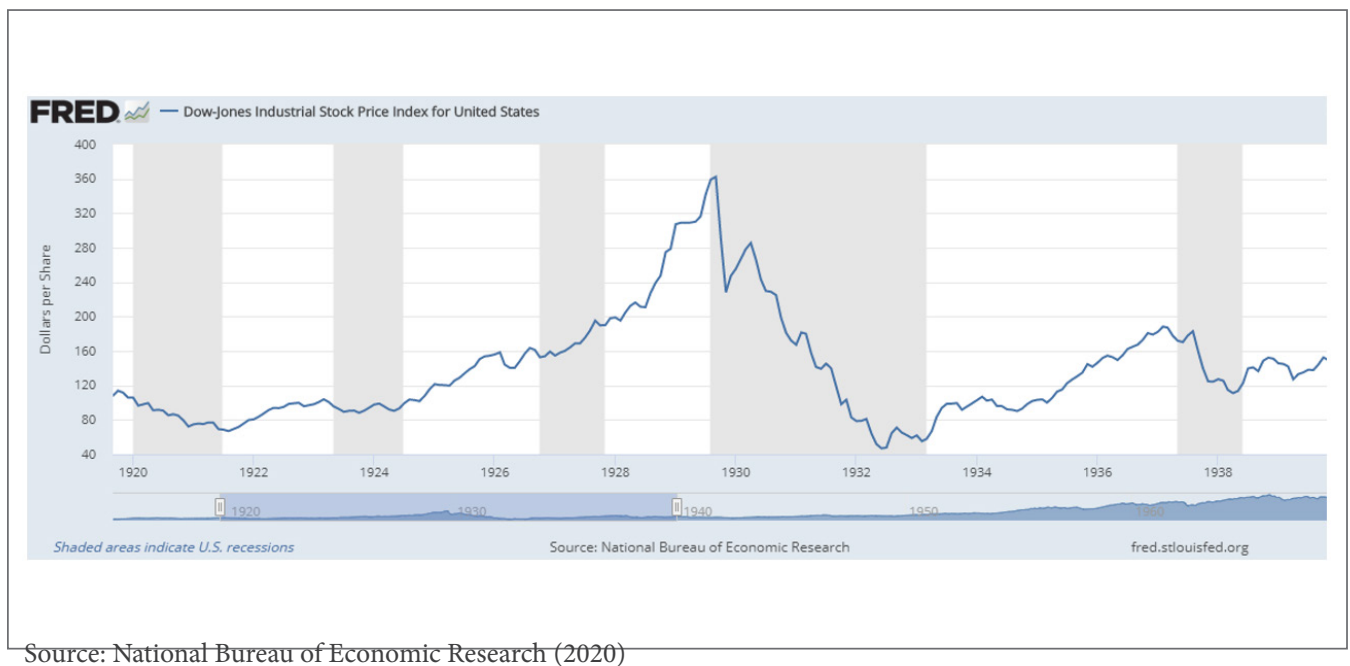

\subsubsection{Corona Crisis}

This section considers an updated look at the S\&P 500 (continuation of Figure 16) due to the Corona Crisis (Figure 18).

The second downturn circled in red shows impressively which stock exchange effects happened due to the Corona pandemic. It is astonishing that the announcement of a rate hike in December 2018 almost brought the index down (December 21, 2018= $2,416.62$ ) and the index level after a global epidemic broke out reached almost the same level (March $20,2020=2,304.92)$. In the detailed analysis it is imperative to take into account that the price drop from the end of November (November 30, $2018=$ 2,760.17) to the end of December 2018 (December $21,2018=2,416.62$ ) does not represent a loss as high as from mid-February 2020 (February 14, $2020=$ 3,380.16) until mid-March 2020 (March 20, $2020=$ 2,304.92). The crash is consequently more drastic and unexpected, but the recovery effect after December 2018 was visibly longer than that after the Corona outbreak (S\&P Dow Jones Indices LLC). At the end of the graphic illustration the recovering trend becomes visual and shows on the one hand that the belief in 


\section{Figure 18}

S\&P 500 Ten Years before and until the Corona Crisis

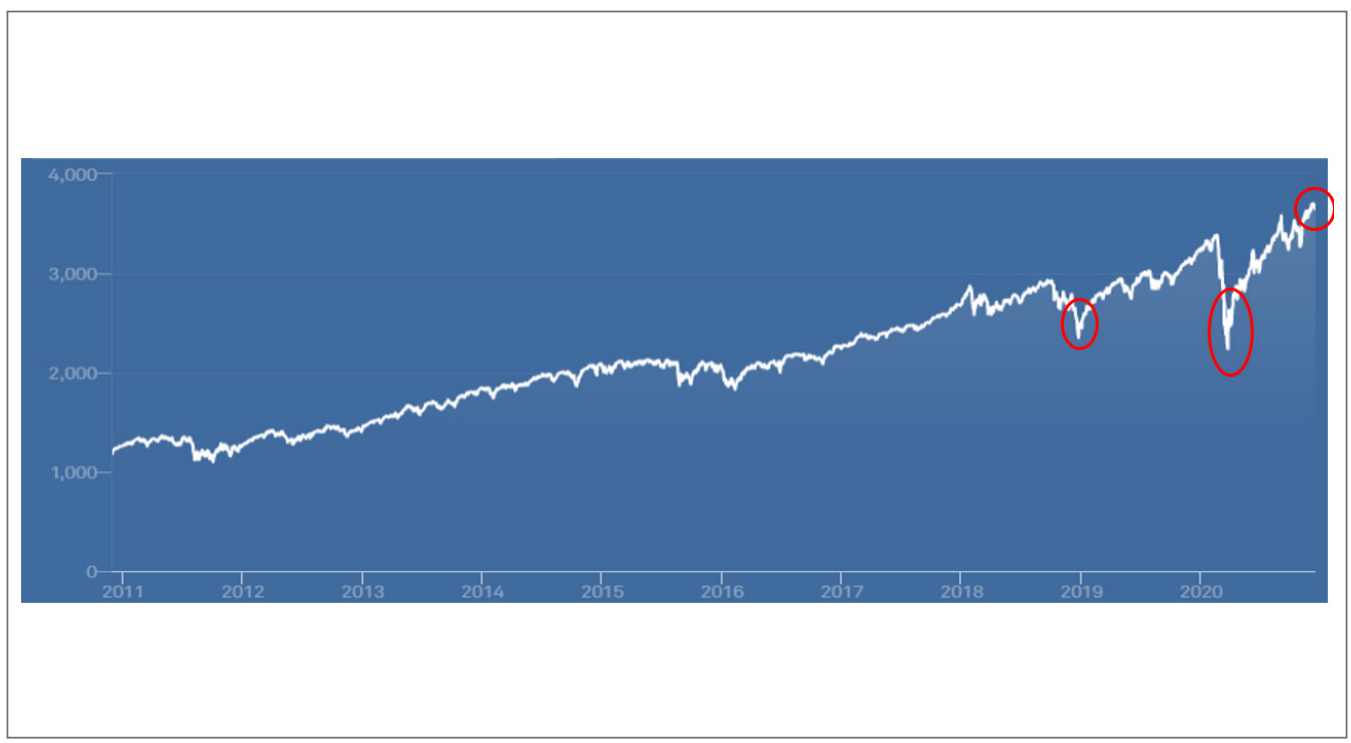

Source: S\&P Dow Jones Indices LLC (as of December 15, 2020)

the economy is present again associated with trust in the stimulus measures combating the crisis. On the other hand, this may be due to Corona-easing measures (Holz, 2020) and the continued efforts to reopen companies and resume activities that have been postponed or restricted due to Covid-19. Finally, the third red circle shows the positive chart effect due to the announcement by various pharmaceutical companies about the expected vaccination periods.

\subsubsection{Comparison of the Partial Results and Preliminary Discussion}

The crisis periods were initially evident in all of the charts shown whereby the intensity of the Great Depression stood out and marked the longest phase in which stock prices suffered. A brief analysis reveals the following findings: In the Great Depression stock markets did not reach the pre-crisis level even after 10 years, in the Great Recession within 5 years and in the Corona Crisis within 1 year (!). These are signs of a stock rally over the years which even a sharp crisis cannot stop.

Additionally, the recovery trends which were mainly based on fiscal policy measures were characteristic of the two recent crises. The recovery periods in the key indices examined after the outbreak of the crisis were largely based on the results of the examination. This included the far-reaching stimulus packages of the respective governments as well as the liquidity aid and key interest rate cuts by the Fed which at first gave investors hope for an economic recovery. In view of the inexorably increasing debt paths (as described in 2.4.) investors clearly only attach a peripheral importance to the perspective and sustainable view. In the context of the comparison between the Great Depression and the Great Recession Straumann said that even in the 1930s the Fed "initially reacted correctly to the stock market crash by quickly reducing nominal interest rates and the banks with liquidity were taken care of." Although it ensured that share prices stabilized in the medium term the economy was still going through a long dry spell as he added: "On the other hand, the Fed reacted too weakly to the subsequent banking crises and international capital movements, not least because the gold standard defied the limited scope. This turned the recession into a depression." While he saw expansionary monetary policy in the first phase in $2008 / 2009$ as an 
adequate and logical step to contain the crisis and calm down the capital markets, he questioned the effect of the subsequent quantitative easing (especially purchase of government bonds) because their effect "cannot be statistically proven beyond any doubt." And this is exactly where it is transferred to the reprehensible. As a difficult circumstance the almost entirely expansionary monetary policy after 2008 did not really ease the general conditions, but increased the debt ratios (Straumann, 2019).

\section{Relation to Economic Theories}

\subsection{Great Depression}

This chapter aims to present relevant economic theories as to show the (expected) results and trajectories of the analyzed indicators under the respective crisis conditions. Starting with the experiences from the Great Depression which shaped Keynes' views and reinforced his skepticism towards classical economic theory (Rothermund, 1993). Regardless of whether his theory is called a "business cycle theory" (Blaich, 1990) or a "revolution" (Galbraith, 1994). His work "General Theory of Employment Interest And Money" (Keynes, 1936) created the basis with which he wanted to convince other economists of the necessity of a fundamentally new macroeconomic economic theory and questioned the prevailing "market optimism", which almost ignored the problem of unemployment. The global effects of the Great Depression called for a theory that explained why the economic development was so devastating and from which state action could be convincingly argued. The "General Theory" no longer focuses on price relations and adjustments, but on the overall demand for goods. In addition, he explained why a regaining of full employment can only be achieved by increasing the overall demand mentioned and not by flexible prices and wages (Rothermund, 1993). What is more interesting is the fact that Keynes' theories were known internationally, but not initially applied. That is why various economists criticized their failure to observe them (Büttner, 1989).

Until the era of the Great Depression, the way of thinking of the so-called "liberal theology" (Galbraith, 1994) existed primarily since the 19th century, in which, according to Galbraith, the view was held "that more competition serves the common good" (Gal- braith, 1994). Matis and Stiefel add contextually that in this type of "economic control" state interventions were rejected as contrary to the system and that rather trusts "the work of the invisible hand, the forces and the self-regulation ability of the market" were incumbent on supply and demand (Matis \& Stiefel, 1991). In addition to the theories above, the monetarists also emerged, both of whom still have a decisive influence on economic science today. In their view an unnecessary shortage of money (deflation) triggered the crisis (Rothermund, 1993). Fisher and Friedman in particular, who are regarded as two of the creators of modern monetary theory (Matis \& Stiefel, 1991), recommend an independent central bank which should steer a monetary policy in the interests of price stability. This ensures that the money supply and economic activity are in harmony with one another (Rothermund, 1993).

A closer look at the two main theories reveals further differences. While Keynesianism as a macroeconomic imbalance theory assumes that markets can get out of balance in the long term, especially in times of crisis, equilibrium-oriented macro theories such as neoclassics or monetarism, on the other hand, assume that markets find their way back to equilibrium quickly. Keynes' criticism is also oriented against the classic assumption that money functions as a pure medium of exchange (Rothermund, 1993). In times of crisis, in particular, there is also the need to hoard money in the bank or to sit on cash instead of spending it. Viewed negatively, this "liquidity preference" promotes the shortage of money, depresses prices and curbs production (Galbraith, 1995). An interventionist countermeasure is required (Rothermund, 1993).

Classical monetary theory, in which money acts purely as a medium of exchange, was not the only economic theory that Keynes argued against. Say's theorem (by Jean-Baptiste Say 1767-1832), was considered to pave the way for a supply theory in which weak demand in the economy was denied. Shaped by the ideas of Smith, the motto for this theory (Galbraith, 1995) was that every production also generates its sales (Matis \& Stiefel, 1991). Overproduction, therefore, is only caused by a temporary misdirection of capital, which in the sense of this theory is caused by "state interventionism, trade union policies, cartels, and tariff protection," which would never have existed under pure market conditions (Matis \& Stiefel, 1991). The sobering 
realization finally came at a time outside the norm, like that of the Great Depression in the 1930s, when the above theory became debatable. Keynes' rejection of Say's law was gradually strengthened in the point that specifically addressed the connection between savings and investments and its effects on employment. He assumed that not all of the savings flow into the economic cycle via the financial market. This interrupts the cycle between saving and investing and means that total demand is less than supply (Galbraith, 1995).

\subsection{Great Recession}

A first notable thesis in the context of economic theories related to the crisis investigation is to be questioned by Plumpe, who explains "that there are in fact no actual crisis theories, but all the more ideas of imbalance, be they necessary or avoidable. The impression is gained, in particular, that for numerous economists of monetarist or Keynesian origin, crises are avoidable phenomena" (Plumpe, 2011). In this context, Piketty cites the tendency to increase social inequality in capitalist societies (Piketty, 2014), which are associated with vulnerability to crises (Galbraith, 2009). From the perspectives above, numerous threads of discussion arose questioning the economic theories that form the substructure of a modern financial system. Above all, the "efficiency market hypothesis" of Fama, whose theory was able to interpret at least parts of the crisis' outbreak. It has been considered as one of the most influential theories in the field of capital market theories since 1970 and pursues his thesis that "the price or rate of a share at the moment of its determination contains everything that was predictable at that time" (Fama, 2009). As a supporter of free markets, he investigated how prices work in the markets and concluded that the Great Recession was not triggered by the curious stock market developments. Rather, it was the surplus of credit in the USA - especially to economically weak citizens - that made the markets develop inefficiently. With the recession at the time, homeowners went bankrupt and that was not the fault of the markets, but that of the politicians.

In addition to the efficiency of the markets, Fama's position was outweighed by skepticism about state intervention in the economy, where he would have preferred to let the companies concerned go bankrupt in order to clean up the market (Fama, 2009). Instead, with the roll-out of comprehensive economic stimulus packages to contain the crisis, the theories of Keynes and Minsky regained relevance. None other than Krugman spoke in the New York Times on November 29, 2008 of the "Keynesian moment" in global economic policy, heralding an elementary reorientation (Krugman, 2008). The neoliberal ideology, represented by important economists like Friedman or politicians like Thatcher, dominated economic activity from the 1980s onwards and was about to be replaced by the state rescue measures (Ther, 2017).

Regarding Minsky, his theory also received a revival. It states that long periods of stability tend to provoke wild swings in the financial markets when market participants such as banks, companies or consumers wake up from their lethargy and are willing to take on more risks in terms of financing in order to increase profit. It is also accompanied by intensive competition between banks, which in such a phase give free rein to their creativity with regard to new financial products. In the following, the theory contains three cycles that describe investor behavior. In the first cycle, investors initially engage in conservative financing ("hedge"), in which most of the economic units (households, investors, and firms) are able to finance all their payment obligations with their cash flows. If this approach proves stable, this leads to the "speculative" cycle in which the borrower can only pay (increased) interests. If the economy continues to develop, the last cycle "Ponzi" scheme - follows. Borrower cannot even make the interest payments, must borrow again to pay them. The economy becomes more unstable and crisis-prone until a financial crisis actually occurs. In summary, it can be said that for Minsky the capitalist system is not stable enough and stability leads to instability. In such extraordinary phases of imbalance and according to Minsky the state had to step in (Minsky, 2008).

\subsection{Corona Crisis}

What was regularly called for in the debates surrounding the climate crisis has become reality in the Covid 19 pandemic. Society largely follows the advice of science in its decisions. Because in the past few months hardly a day has passed without a virologist taking a position on the infection process and pointing out measures that should help contain the pandemic. Epidemiological terms such as "herd 
immunity," "doubling time," and "reproductive rate" has now become part of everyday language and determines politics and social life. Political advice is not only provided by virologists and epidemiologists, the opinions of medical ethicists, educators, lawyers and sociologists are also sought. But what ultimately falls short in the scientific public discourse is the voice of economics (Althammer \& Naß, 2020).

One example of missing thw economic voice was the giving up of an inflation target which contradicts the basic order of classic economic principles and theories. This can be derived, for example, from Powell's decision on August 27, 2020 which can be interpreted as a historical change in strategy (Powell, 2020). In economic theory, an optimal inflation rate could be calculated theoretically, but in practice an exact quantification is only possible to a limited extent. Even according to Keynesian theories, it is difficult to derive an optimal inflation rate; rather, according to Kulessa, "demand-theoretical models suggest a kind of context-dependent optimal inflation corridor." This theory hides the premise that expansive macro-policy (as it has been pursued in the EU and the USA in recent years) can be accompanied by an increase in employment and that is desirable even if it causes the inflation rate to rise noticeably above $2 \%$. Economic policy has its duty to carry out a qualitative analysis of the the inflation's pros and cons and to derive an optimal target inflation rate based on that (Kulessa, 2018).

When looking at other specifics of the current crisis combined with a look at economic theories, there is one peculiarity that cannot be found in comparison to the Great Depression and Great Recession. In both of the crises mentioned, the state rescue measures through austerity measures or taxpayers' money caused a lot of bitterness, because in the eyes of the population the greed and irresponsible behaviour of speculators and bank managers was discovered as a major cause (Fuest, 2020). In contrast, questions about economic costs of the shutdown and the lavish aid packages are considered cold-hearted in the Corona Crisis and the attempt by some economists to assign a monetary value to health and human life as immoral (German Ethics Council, 2020).

Whatever the effect of the rescue measures in the final accounts, there is no doubt about their volumi- nous dimensions. It gives the impression that we are in a phase of so-called "helicopter money." This economic theory goes back to Friedman, whose remarks describe this special effect of an unconventional measure in order to create a money-financed fiscal incentive. Examples such as direct payments, the Paychek Protection Program, emergency aid in the form of direct transfers, bridging aid or not repayable loan advances are evidence of this fact. Specifically, Friedman names it "Bonanza from heaven" (Friedman, 1969).

\section{Conclusions}

The subject of the entire work focused on economic indicators related to three major crises, the Great Depression as a global economic crisis of the 1930s, the Great Recession as a financial crisis beginning in $2007 / 2008$ and the current Corona pandemic as a health crisis with its serious global economic effects. The study produced remarkable findings. All three crises have their own anatomical peculiarities at the level of the indicators examined but there are more parallels than the initial characteristics of each of the individual crises examined would have suggested.

Furthermore, this study points to some recurring patterns and trends that resulted from the comparative analysis of the above indicators in the course of the crises. The investigation has shown that certain patterns exist according to which crises can form. Starting with the first economic indicator, the key interest rate, it could be sketched that an increase in this over a period of a century ended in 16 out of 19 cases in a recession. With regard to financial crises, it could be stated that every financial crisis was preceded by a rate hike cycle (see section 2.1.). However, this first realization should not give the impression that an increase in the key interest rate, which has the purpose of achieving a normalization of interest rates, would be intolerable in the future. With the beginning of the lowering of the key interest rates to a long-term 0 to $1 \%$ level, the so-called quantitative easing programs were started. They are characterized by an unconventional form of expanding the monetary base. The resulting monetary flooding of the markets is the starting point for criticism from various economists, who exaggerated it by saying that "the money... is already coming out to the ears anyway (Sinn, 2020b).” And 
yet the announcement of multiple interest rate hikes in December 2018 was received extremely sensitively by market participants, as the associated stock market development at the time showed (see subsections 2.5.1 and 2.5.4).

In addition to the inflation section, far-reaching insights were also drawn up that largely meet the thesis of a recurring pattern in the context of the crisis. Based on the results of the investigation and a historical review in the USA the prevailing inflation or deflationary developments are mostly directly or indirectly related to signs and consequences of a crisis. Even if inflation levels did not degenerate in the past crises, including the three crises examined, the deflationary tendencies after the outbreak were according to the slogan "recession kills inflation" all the more clearly to be observed (in all three crises) (Smith, 2008). In view of preventive crisis work attention should be paid to the post-crisis deflationary developments in order to eliminate so-called secondround effects, especially in the form of falling wages. Further inflationary developments after the crisis, like GDP, are closely linked to countercyclical fiscal policies (whether implemented or not). Depending on the application this correlates with the measures behind it and is based on the economic theory threads. In their study, Fratzscher and Kriwoluzky refer to the lack of demand-stimulating monetary policy in the 1930s which largely failed to produce a "strong" response from the central banks compared to the Great Recession. In both eras GDP plummeted within a year and government responses varied. They argue that "many have learned from a historical perspective, especially from the Great Depression of 1929 to 1933 " and that a relaxed monetary policy is therefore understandable to increase demand for consumption and investment again, "even if some German critics doubt this (Fratzscher \& Kriwoluzky, 2020).” As a first intermediate conclusion it can be stated that there is no uniform understanding of crisis management strategies, but that a pluralism for understanding solutions can be found. In this context and previous research results it certainly appears that Werner's thesis regarding bubble formation on the financial markets must be taken into account which always "end in a banking crisis", "if bank money creation is growing significantly faster than the economy for a longer period of time (Werner, 2012)." The situation is then further complicated if regulatory mechanisms in the financial markets do not work and spill over into the banking sector (Krugman, 2009).

One of the key findings in this work is the steadily increasing private and public debt ratios for years, particularly caused by the causes and consequences of the Great Recession. The observation predominates that rising debt ratios were reported in all three crises, but in different forms (see Figure 15). However, it would be too easy to judge the current development, as the relevant background must first be considered. While private debt ratios have risen disproportionately due to the low interest rate level coupled with property purchases since the turn of the millennium, the extensive stimulus packages have resulted in a steady increase in public debt ratios. Finding the right consensus and the right arithmetic of rising debt and economic stimulus remains a scientific sparring. What is certain is that the opinion remains broad and predominant, that debt discipline has extremely waned and overstretched. This also means that a tripling of the money supply due to the extensive monetary policy instruments is difficult to reconcile with the idea of sustainability (see Sinn, 2020b). The danger and the risk, as Reinhart and Rogoff put it, remain (in) debatable. According to their complex studies that overstretched debt ratios pose serious difficulties for states, care should be taken with caution ("Private debts surge immediately before banking crises," "High external debt ratios often signal financial distress," Reinhart \& Rogoff, 2009; or "Banking crises most often either precede or coincide with sovereign debt crises," Reinhart \& Rogoff, 2011). The result is that their use is important. Here Werner differentiates according to different types, which underlines the guiding principle. Bank loans should always be answered in the affirmative if they generate "productive" added value, for example for investment loans (Werner, 2012). If you look at the overall picture of the current crisis situation, you can see that even before the outbreak of the Covid-19 pandemic many economists classified the situation as dangerous ("avalanche of debts": Sinn, 2020 b or "unsustainable" mountains of debt: Plickert, 2013) which has now clearly revived the discussion. Whether Corona should serve as a catalyst for system 
errors (Haselmann, 2020) opens up additional scope for interpretation. It means that central bankers and states can now blame virus for bad economic performance, they have an excuse for their previous policy and enormous debt bubble.

In addition to the four indicators above, there was another finding that the slump in the stock markets was significantly shorter than in the Great Depression and that prices only knew the upward direction until the first quarter of 2020. It is unbelivable to what extent financial markets positively react on money printing and low interests, significantly more than on fundamentals or geopolitical tensions (Sinković, 2020b). What certainly appears from an all-round view of the entire study is that greater sensitivity on the financial markets can be expected in the coming years and that policymakers' sense of observation should be sharpened. The current crisis therefore continues to pose very great challenges for both politicians and central banks to find more sustainable solutions and win the trust of the population. Among other things, this should also be due to the viewpoint that with the issuance of the costly and extensive economic stimulus packages new debt has grown to a dimension whose numerology not only brings about dizzying character for the inclined reader, but also burdens subsequent generations with legacy issues. It should provide food for thought for the post-Corona Crisis period.

\section{References}

Abromeit, H., \& Stoiber, M. (2006). Demokratien im Vergleich - Einführung in die vergleichende Analyse politischer Systeme [Comparing democracies - An introduction to comparative analysis of political systems]. Springer.

Agresti, J. D. (2020, June 10). National debt breaks alltime record for highest portion of U.S. Economy. Just Facts - Seize the data. Retrieved from https:// www.justfacts.com/news_national_debt_breaks_ record_highest_portion_economy

Althammer, J., \& Nass, E. (2020). Warum findet die Wirtschaftsethik in der Krise kaum Gehör? - Die normativen Grenzen der ökonomischen Theorie im Pandemie-Diskurs [Why is business ethics hardly heard in the crisis? - The normative limits of economic theory in the pandemic discourse]. In Brink, A./Hollstein, B./Neuhäuser, C./Hüb- scher, M. C. (Eds.). Lehren aus Corona: Impulse aus der Wirtschafts- und Unternehmensethik - Zeitschrift für Wirtschafts- und Unternehmensethik / Sonderband, 35-43. Baden-Baden: Nomos. https://doi.org/10.5771/9783748909460.

Bernanke, B. (2013). The Federal Reserve and the Financial Crisis. Princeton University Press.

Berg-Schlosser, D., \& Müller-Rommel, F. (2003). Vergleichende Politikwissenschaft. Comparative politics. Wiesbaden: Springer. https://doi. org/10.1007/978-3-322-86382-9.

Blaich, F. (1990). Der schwarze Freitag - Inflation und Wirtschaftskrise. Black Friday - inflation and economic crisis. Deutscher Taschenbuch Verlag.

Bloch, M. (2000). Aus der Werkstatt des Historikers [From the workshop of the historian]. Campus Verlag.

Bloss, M., Ernst, D., Häcker, J., \& Eil, N. (2009). Von der Subprime-Krise zur Finanzkrise - Immobilienblase: Ursachen, Auswirkungen, Handlungsempfehlungen [From the Subprime Crisis to the financial crisis - real estate bubble: causes, effects, recommendations for action]. Oldenbourg.

Board of Governors of the Federal Reserve System (2019). Credit and liquidity programs and the balance sheet (as of December 8, 2019). Retrieved December 08, 2019, from https://www.federalreserve.gov/monetarypolicy/bst_recenttrends.htm

Board of Governors of the Federal Reserve System (2020). Effective federal funds rate. Federal Reserve Bank of St. Louis. Retrieved April 22, 2020, from https://fred.stlouisfed.org/series/FEDFUNDS

Brunner, J. (2009). Finanzkrise 2008 - Wie es dazu kam und mit welchen Folgen wir rechnen müssen! [Financial Crisis 2008 - How it came about and what consequences we have to expect!]. Buchkirchen.

Bryan, M. (2013, November 22). The Great Inflation. Federal Reserve History. Retrieved from https:// www.federalreservehistory.org/essays/great_inflation

Büttner, U. (1989). Politische Alternativen zum Brüningschen Deflationskurs [Political alternatives to Brüning's deflationary course]. Vierteljahrshefte für Zeitgeschichte, 37(2), 209-251.

Congressional Budget Office of the United States (2020). The budget and economic outlook: 2020 to 2030. Report 56020. Washington.

Daniel, V., \& ter Steege, L. (2020). Inflation expectations and the recovery from the Great Depression in Germany. Explorations in Economic History, 75 (C), 101305. https://doi.org/10.1016/j. 
eeh.2019.101305

Davies, G. (2012, July 7). Lessons from the Fed's Mistake of 1932. Financial Times. https://www.ft.com/ content/d83ed76e-b2d0-3fa4-8cd2-e397c484f2d5

Fama, E. (2009, February). "Theorien, die funktionieren, überleben". "Theories that work survive". Institutional money. https://www.institutionalmoney.com/drucken/magazin/theorie-praxis/ artikel/eugene-fama-im-interview-theorien-diefunktionieren-ueberleben-7360/

Federal Open Market Committee/FED (2018). Chairman Powell's press conference December 19, 2018. Retrieved from https://www.federalreserve.gov/ mediacenter/files/fomcpresconf20181219.pdf

Federal Open Market Committee/FED (2019). Chairman Powell's press conference October 30, 2019. Retrieved from https://www.federalreserve.gov/ mediacenter/files/FOMCpresconf20191030.pdf

Federal Reserve Bank of St. Louis (2012). Real gross domestic product/industrial production index. Retrieved July 10, 2020 from research.stlouisfed. org

Federal Reserve Bank of St. Louis (2020). Federal debt: Total public debt as percent of gross domestic product. FRED. Retrieved May 13, 2020 from https://fred.stlouisfed.org/series/GFDEGDQ188S

Finanzen.net (2020). Current key interest rate. Retrieved December 15, 2020 from https://www. finanzen.net/zinsen/leitzins.

Fratzscher, M., \& Kriwoluzky, A. (2020). Über die Ursachen und das mögliche Ende der niedrigen Zinsen in Deutschland [About the causes and the possible end of the low interest rates in Germany]. Wirtschaftsdienst, 100(1), 12-16. https://doi. org/10.1007/s10273-020-2553-2

Fricke, T. (2016, October 14). Amerika vor der Wahl - Obamas Wirtschaftswunder [America before the election - Obama's economic miracle]. Wirtschaftswunder. Retrieved from https://neuewirtschaftswunder.de/2016/10/14/ thomas-fricke-amerika-vor-der-wahl-obamaswirtschaftswunder/

Friedman, M. (1969). The optimum quantity of money. In: Friedman, M. (Ed.). Introduction by Bordo, M. D. Aldine Transaction Publishers.

Friedman, M., \& Schwartz, A. J. (1963). A monetary history of the United States, 1867-1960. Princeton University Press.

Fuest, C. (2020). Wie wir unsere Wirtschaft retten - Der Weg aus der Corona-Krise [How we save our economy - the way out of the Corona Crisis]. Aufbau Verlag.
Galbraith, J. K. (1995). Die Geschichte der Wirtschaft im 20. Jahrhundert: ein Augenzeuge berichtet (translated from the American by Wiermann) [The history of the economy in the 20th century: an eyewitness recounts]. Hoffmann \& Campe.

Galbraith, J. K. (2009). Der große Crash 1929 - Ursachen, Verlauf, Folgen [The great Crash of 1929 Causes, course, consequences]. FinanzBuch Verlag.

German Ethics Council (Deutscher Ethikrat) (2020). Solidarität und Verantwortung in der CoronaKrise. Ad-hoc-Empfehlung [Solidarity and responsibility in the Corona Crisis. Ad hoc recommendation]. (March 27). Retrieved from: https:// www.ethikrat.org/fileadmin/Publikationen/AdhocEmpfehlungen/deutsch/ad-hoc-empfehlungcorona-krise.pdf.

Grömling, M. (2020). Corona-Krise und die deutsche Wirtschaft. Corona Crisis and the German economy. Institut der deutschen Wirtschaft/German Economic Institute IW-Kurzberichte, 15/2020.

Haselmann, G. (2020, March 8). Coronavirus - the catalyst for system failure. Advisoranalyst. Retrieved from https://www.zerohedge.com/markets/coronavirus-catalyst-system-failure

Herz, B. (2020). Expertenmeinung zu Globalisierung und wirtschaftlichen Auswirkungen der CoronaPandemie [Expert opinion on globalization and economic impact of the Corona pandemic]. Universität Bayreuth. Press release (No. 42) March 23, 2020. Retrieved from https://www.presse. uni-bayreuth.de/de/archiv/2020/042-TextserieCorona-Herz.pdf

Holz, T. (2020, June 29). Rasche Erholung am Aktienmarkt nach Corona - Blase oder keine Blase? [Rapid recovery on the stock market after Corona - bubble or no bubble?] finanzen.net. Retrieved from https://www.finanzen.net/nachricht/aktien/volatile-boerse-rasche-erholungam-aktienmarkt-nach-corona-blase-oder-keineblase- 9008408

Illing, G. (2014). Staatsverschuldung und Finanzkrise - Wechselwirkungen und Krisenpotenziale [Public debt and financial crisis - interactions and crisis potentials]. Metropolis.

International Monetary Fund (2020) - IMF DataMapper. Retrieved October 10, 2020 from https://www. imf.org/external/datamapper/datasets/WEO

Jahn, D. (2013). Einführung in die vergleichende Politikwissenschaft [Introduction to comparative politics]. Springer.

Jahnke, J. (2008). Weltwirtschaftskrise II - Eine kom- 
plette Analyse von Entstehungsgründen und Ausmaß der globalen Krise [World Economic Crisis II - A complete analysis of the causes and extent of the global crisis]. Shaker Media.

Jahnke, J. (2009). Die zweite Große Depression - Wo die Krise herkommt, Wo sie hinführt, Was tun? [The second Great Depression - Where the crisis comes from, where it leads, what to do?] Shaker Media.

James, H. (2001). The end of Globalization: Lessons from the Great Depression. Harvard University Press.

James, H. (2003). Der Rückfall - Die neue Weltwirtschaftskrise. The Relapse - The New Global Economic Crisis. Piper Verlag.

Jones, C. (2020, April 25). Coronavirus, CARES and PPP will explode the Federal deficit and debt. Forbes. https://www.forbes.com/sites/chuckjones/2020/04/25/the-coronavirus-will-explodethe-federal-deficit-and-debt/\#3de863ab7ef7

Jordà, Ò., Schularick, M., \& Taylor, A. M. (2016). Macrofinancial history and the new business cycle facts. Federal Reserve Bank of San Franciso Working Paper, (No. 28). https://doi.org/10.3386/w22743

Keynes, J. M. (1936). The General Theory of Employment, Interest and Money. Macmillan.

Kindleberger, C. P. (1973). Die Weltwirtschaftskrise 1929-1939. The Great Depression of 1929-1939. Translated German edition. In W. Fischer (Ed.) Geschichte der Weltwirtschaft im 20. Jahrhundert (pp. 1-343) - Vol. 2. dtv Deutscher Taschenbuch Verlag.

Kooths, S. (2020). Update Konjunkturbericht: Deutsches BIP dürfte 2020 zwischen 4,5 und 9 Prozent einbrechen [Economic report update: German GDP likely to slump between 4.5 and 9 percent in 2020]. Kieler Institut für Weltwirtschaft. Retrieved April 5, 2020 from https://www.ifw-kiel.de/ $\mathrm{de} /$ publikationen/medieninformationen/2020/ update-konjunkturbericht-deutsches-bip-duerfte-2020-zwischen-45-und-9-prozent-einbrechen/

Kremer, D. (2017, June 5). Häuser ohne Wert. Houses without value. FAZ.NET. Retrieved from https://www.faz.net/aktuell/finanzen/finanzkrise-haeuser-ohne-wert-groesste-immobilienkrise-15046364.html?printPagedArticle $=$ true\#vo id

Krugman, P. (2008, November 29). The Keynesian moment. New York Times (November 29). Retrieved from https://krugman.blogs.nytimes. com/2008/11/29/the-keynesian-moment/.

Krugman, P. (2009). The Return of Depression Econom$i c s$ and the Crisis of 2008. Norton \& Company.
Krugman, P. (2012, October 8). Anzeichen einer Krise à la 30er-Jahre? [Signs of a crisis à la the 1930s?] Fondsprofessionell. Retrieved from https://www. fondsprofessionell.de/drucken/news/maerkte/ headline/nobelpreistraeger-krugman-anzeicheneiner-krise-a-la-30er-jahre-105572/

Krugman, P. (2019, December 21). Deutschland sollte Schulden machen. Germany should incur debt. Tagesschau.de. Retrieved from https://www.tagesschau.de/ausland/krugman-interview-101. html

Kulessa, M. (2020). Makroökonomie im Gleichgewicht: Praxis und Theorie [Macroeconomics in equilibrium: practice and theory]. Konstanz/Munich: UTB GmbH.

Lang, S. (n.d.) Empirische Forschungsmethoden [Empirical research methods]. Retrieved February 20, 2020 from https://www.uni-trier.de/fileadmin/ fb1/prof/PAD/SP2/Allgemein/Lang_Skript_komplett.pdf

Massing, O. (1974). Vergleichende Politische Analyse (Comparative Government and Politics). In O. Massing (Ed.). Politische Soziologie - Paradigmata einer kritischen Politikwissenschaft. Suhrkamp.

Matis, H., \& Stiefel, D. (1991). Die Weltwirtschaft Struktur und Entwicklung im 20. Jahrhundert [The world economy - structure and development in the 20th century]. Carl Ueberreuter.

Minsky, H. P. (2008). Stabilizing an unstable Economy. McGraw-Hill.

Münchau, W. (2008). Kernschmelze im Finanzsystem. Meltdown in the financial system. Carl Hanser.

National Bureau of Economic Research. (2020). Dow Jones Industrial Stock Price Index for United States. Federal Reserve Bank of St. Louis, Retrieved May 22, 2020 from https://fred.stlouisfed. org/series/M1109BUSM293NNBR

Naumer, H.-J. (2020, June 11). Zinstief entlastet Deutschland beim Abtragen neuer Schulden. Low interest rates ease the burden on Germany when it comes to paying off new debt. Handelsblatt.com. Retrieved from https://www.handelsblatt.com/ finanzen/banken-versicherungen/coronakrise-allianz-zinstief-entlastet-deutschland-beim-abtragen-neuer-schulden/25907774.html?ticket=ST3960080-xbwcmPef1SlirRGGNmsY-ap4

Nizam, R., Karim, Z. U., Rahman A. A., \& Sarmidi, T. (2020). Financial inclusiveness and economic growth: new evidence using a threshold regression analysis. Economic ResearchEkonomska Istraživanja, 33 (1), 1465-1484. DOI: 10.1080/1331677X.2020.1748508 
Nohlen, D. (1994). Vergleichende Methode. Comparative Method. In J. Kriz, D. Nohlen, \& R.-O. Schultze (Eds.). Lexikon der Politik, Politikwissenschaftliche Methoden - Vol. 2. C.H.Beck.

Piketty, T. (2014). Das Kapital im 21. Jahrhundert. Capital in the 21st century. Munich: C.H. Beck.

Plickert, P. (2013, May 20). Der deutsche Schuldenberg ist auf Dauer untragbar. Germany's mountain of debt is unsustainable in the long term. FAZ.NET. Retrieved from https://www.faz.net/ aktuell/wirtschaft/staatsfinanzen-der-deutscheschuldenberg-ist-auf-dauer-untragbar-12188759. html\#void

Plumpe, W. (2011). Wirtschaftskrisen - Geschichte und Gegenwart [Economic crises - past and present]. Munich, C.H. Beck.

Powell, J. (2020, May 17). 60 Minutes interview on economic recovery from the coronavirus pandemic with S. Pelley. CBS News. Retrieved from https://www.cbsnews.com/news/full-transcriptfed-chair-jerome-powell-60-minutes-intervieweconomic-recovery-from-coronavirus-pandemic/

Przeworski, A. (1987). Methods of cross-national research 1970-83. An overview. In M. Dierkes, H. N. Weiler, \& A. Berthion Antal (Eds.). Comparative policy research: Learning from experience (pp. 31-49). Gower.

Reed, S. B. (2014). One hundred years of price change: the Consumer Price Index and the American inflation experience. Monthly Labor Review, 137 (4_7), 1-9. DOI: https://doi.org/10.21916/mlr.2014.14

Reinhart, C. M., \& Rogoff, K. S. (2009). This time is different - Eight Centuries of Financial Folly. Princeton University Press.

Reinhart, C. M., \& Rogoff, K. S. (2011). From financial crash to debt crisis. American Economic Review, 101 (5), 1676-1706. 10.1257/aer.101.5.1676

Rothermund, D. (1993). Die Welt in der Weltwirtschaftskrise 1929-1929 [The world in the Great Depression 1929-1929]. Muenster - Hamburg: Lit-Verlag.

S\&P 500 (2020). In finanzen.net database. Retrieved January 15, 2020, from https://www.finanzen.net/ index/s\&p_500

S\&P Dow Jones Indices LLC (2020). Ticker SPX chart performance. Retrieved August 1, 2020, https:// us.spindices.com/indices/equity/sp-500

Schmidt, M. G. (1988). Einführung. Introduction. In M. G. Schmidt (Ed.), Staatstätigkeit. International und historisch vergleichende Analysen [State activity. International and historical comparative analyzes]. Politische Vierteljahresschrift
Special Edition, 29 (19), 1-35. DOI: https://doi. org/10.1007/978-3-322-83620-5_1

Seidl, B., \& Brandt, M. (2018). 90 Jahre Schwarzer Freitag an der Berliner Börse [ 90 years of Black Friday on the Berlin Stock Exchange]. ard.de. Retrieved from https://multimedia.boerse.ard.de/schwarzer-freitag-berliner-boerse\#3653

Sinković, D. (2020a, March 30). Konačan slom - Korona Kriza Ekonomska Analiza [Final Breakdown - Corona Crisis Economic Analysis]. Glas Istre. https://www.glasistre.hr/gospodarstvo/konacanslom-globalne-ekonomije-dean-sinkovic-profesor-s-pulskog-fet-a-ekskluzivno-za-glas-istre-donosi-detaljnu-analizu-632563

Sinković, D. (2020b, June 6). Zdravlje, znanje i sigurnost temelj su uspješnih gospodarstava [Health, knowledge and safety are the foundation of successful economies]. Glas Slavonije. Retrieved from https://www.glas-slavonije.hr/434198/11/DeanSinkovic-Zdravlje-znanje-i-sigurnost-temelj-suuspjesnih-gospodarstav

Sinn, H.-W. (2020a, March 15). Wie eine Corona-Ökonomie aussehen muss [What a Corona economy should look like]. Handelsblatt.com. Retrieved from https://www.handelsblatt.com/ meinung/gastbeitraege/gastkommentar-wie-einecorona-oekonomie-aussehen-muss/25642468. html ? ticket $=$ ST -373864 - a 6 d L 5 h Opl 4 svrOGerNdJ-ap3

Sinn, H.-W. (2020b, April 3). Coronabonds führen zu einer Verschuldungslawine, die nichts als Hass und Streit übrig lassen wird [Corona bonds lead to an avalanche of debt that will leave nothing but hatred and strife]. Interview by O. Götz. Börse am Sonntag. Retrieved from https://www.boerseam-sonntag.de/aktien/markt-im-fokus/artikel/ hans-werner-sinn-warnt-vor-corona-bonds-undverschuldungslawine.html

Smith, A. (2008, August 14). Inflation surges to 5.6\%. CNN Money, Special Report. Retrieved from https://money.cnn.com/2008/08/14/news/economy/cpi/index.htm

Soros, G. (1998). The crisis of global capitalism: Open society endangered. Public Affairs.

Stoeferle, R.-P., \& Valek, M. J. (2017). Gold and the turning of the monetary tides. In gold we trust report from Incrementum AG (June 1, 2017).

Stoeferle, R.-P., \& Valek, M. J. (2018). Gold and the turning of the monetary tides. In gold we trust report 2018 from Incrementum AG (May 29, 2018). Straumann, T. (2019, October 24). Auch in den 1920er Jahren waren die Zinsen über eine längere Zeit zu 
tief [Interest rates were also too low for an extended period in the 1920s]. Interview by M. Ferber. Neue Zürcher Zeitung. Retrieved from https:// www.nzz.ch/finanzen/boersen-crash-parallelenzwischen-1929-und-heute-ld.1517224

Szyszko, M., Rutkowska, A., \& Kliber, A. (2020). Inflation expectations after financial crisis: Are consumers more forward-looking? Economic ResearchEkonomska Istraživanja, 33 (1), 1052-1072. DOI: 10.1080/1331677X.2019.1595083

Ther, P. (2017). Eine Einführung in die Geschichte des Neoliberalismus [An introduction to the history of Neoliberalism]. In Olteanu, T./Spöri, T./ Jaitner, F./Asenbaum, H. (Eds.). Osteuropa transformiert - Sozialismus, Demokratie und Utopie, 125-153. Wiesbaden: Springer. DOI: https://doi. org/10.1007/978-3-658-17818-5_8.

U.S. Bureau of Labor Statistics (2020a, May 12). Economic news release - consumer price index summary April 2020. Retrieved https://www.bls.gov/ news.release/archives/cpi_05122020.htm

U.S. Bureau of Labor Statistics (2020b, December 10): Economic news release - consumer price index summary November 2020. Retrieved https://www. bls.gov/news.release/archives/cpi_12102020.htm

U.S. Bureau of Economic Analysis (2020, April 29). Gross domestic product, 1st Quarter 2020 (Advance estimate). Retrieved https://www.bea.gov/ news/2020/gross-domestic-product-1st-quarter2020-advance-estimate

U.S. Bureau of Economic Analysis (2020). Gross domestic product; FRED; Retrieved May 25, 2020, from https://fred.stlouisfed.org/series/GDP

U.S. Department of the Treasury Bureau of the Fiscal Service (2020a, March 31). TreasuryDirect - Public Debt Reports. Retrieved June 5, 2020, from https://reasurydirect.gov/govt/reports/pd/ pd_debttothepenny.htm

U.S. Department of the Treasury Bureau of the Fiscal Service (2020b, June 11). TreasuryDirect - Public debt reports. Retrieved June 15, 2020, from https://treasurydirect.gov/govt/reports/pd/pd_ debttothepenny.htm

U.S. Department of the Treasury (2020c). The CARES act works for all Americans. Retrieved June 03, 2020, from https://home.treasury.gov/policyissues/cares

U.S. Department of Labor: Bureau of Labor Statistics (2014). Consumer price index for all urban consumers (all items). Retrieved from https://research.stlouisfed.org/

Werner, R. A. (2002, June 27). Das Zentralbanken-
Komplott. The central bank plot. Der Standard. Retrieved from https://www.derstandard.at/story/926535/das-zentralbanken-komplott

Werner, R. A. (2012). Geld- und Zinswirtschaft ohne volkswirtschaftliches Wachstum. Denkwerk Zukunft - Konferenz Leben ohne Zins und Wachstum [Money and interest economy without economic growth. Denkwerk Zukunft - Conference life without interest and growth]. Retrieved from http://www.denkwerkzukunft.de/downloads/ Konferenz2012/Impuls_Richard_Werner.pdf

Wheelock, D. C. (2007). The Great Depression: An overview. Federal Reserve Bank of St. Louis. Retrieved from https://www.stlouisfed.org/ /media/ files/pdfs/great-depression/the-great-depressionwheelock-overview.pdf

World Bank (2020). Inflation, consumer prices for the United States (FPCPITOTLZGUSA), Federal Reserve Bank of St. Louis. Retrieved April 23, 2020, from https://fred.stlouisfed.org/series/FPCPITOTLZGUSA

Zeise, L. (2009). Das Ende der Party - Die Explosion im Finanzsektor und die Krise der Weltwirtschaft [The end of the party - The explosion in the financial sector and the crisis in the world economy]. Papyrossa.

Zschäpitz, H. (2019, February 14). Zieht die EZB die extremste Waffe der Geldpolitik? [Is the ECB pulling the most extreme weapon of monetary policy?] Welt.de. Retrieved from https://www.welt.de/ finanzen/article188758349/Helikoptergeld-Ziehtdie-EZB-die-extremste-Waffe-der-Geldpolitik. html

Zürn, M. (2020). Globalisierung nach Corona: Zurück in die Zukunft? [Globalization after Corona: back to the future?] Wissenschaftszentrum Berlin für Sozialforschung. Retrieved August 1 from https:// wzb.eu/de/forschung/corona-und-die-folgen/globalisierung-nach-corona-zurueck-in-die-zukunft 